\title{
Copper-based non-precious metal heterogeneous catalysts for environmental remediation
}

\author{
Yarong Fang, Yanbing Guo * \\ Key Laboratory of Pesticide \& Chemical Biology of Ministry of Education, Institute of Environmental and Applied Chemistry, College of Chemistry, Central \\ China Normal University, Wuhan 430079, Hubei, China
}

\section{A R T I C L E I N F O}

\section{Article history:}

Received 30 November 2017

Accepted 31 December 2017

Published 5 April 2018

\section{Keywords:}

Copper-based catalyst

Heterogeneous reaction

CO oxidation

Selective catalytic reduction

Volatile organic compounds oxidation

Organic pollutant degradation

Soot combustion

\begin{abstract}
A B S T R A C T
This paper presents a detailed review of copper-based catalysts used in wide-ranging environmental remediation, including gas, liquid and solid phase pollutant elimination. Latest advances in the remarkable catalytic activity of copper-based catalysts, including bulk $\mathrm{CuO}_{x}$, supported $\mathrm{CuO}_{x}$, and solid solution $\mathrm{CuO}_{x}-\mathrm{X}$ are emphasized. The structure-activity relationships among the crystal structure, morphology, catalyst support, and catalytic performance in specific catalytic reactions for environmental remediation are discussed. Furthermore, current obstacles faced by Cu-based catalysts and potential strategies to address them have been proposed, which may aid the future research and development of highly efficient $\mathrm{Cu}$-based non-precious metal catalysts.
\end{abstract}

(c) 2018, Dalian Institute of Chemical Physics, Chinese Academy of Sciences. Published by Elsevier B.V. All rights reserved.

\section{Introduction}

The rapid growth of the global economy and industrialization in the past century has caused serious environmental problems that greatly influence the sustainability of human society and seriously effect human health [1]. Gaseous, liquid, and solid pollutants are released from both industrial and mobile sources [2]. Carbon monoxide (CO) is toxic and detrimental to all respiring life forms, particularly humans [3], and contributes indirectly to atmospheric chemistry and subsequent global warming and ozone depletion. Nitrogen oxides $\left(\mathrm{NO}_{x}\right)$ [4] and sulfur dioxide $\left(\mathrm{SO}_{2}\right)$, generated by burning fossil fuels, vehicles, manufacturing, oil refineries, and other industries, are the main causes of acid rain, which has a severe effect on ecosystems and human health [5]. Volatile organic compounds (VOCs) are not only hazardous air pollutants, due to their toxic, malodorous, mutagenic, and carcinogenic properties [6], but also precursors to ozone and smog due to their photochemical reactivity in atmosphere [7]. Industrial organic pollutants in wastewater, typically containing stable aromatic molecular structures that are difficult to degrade, are major hazards to the environment due to their toxicity and persistence [8]. As a solid pollutant, particulate matter is also harmful to human health because it can be inhaled deep into lungs and enter the bloodstream [9].

Tremendous effort has been made to control the release of pollutants due to growing concerns over climate change, our ecological footprint, and human health. Much of this research has concentrated on developing robust and highly efficient catalysts for environment remediation. Noble metal catalysts (Pt [3,4] and Pd [10]) are generally very active [11], but suffer from their high cost and severe activity degradation resulting from poisoning by contaminants, such as chloride compounds

\footnotetext{
* Corresponding author. Tel: +86-17786507005; E-mail: guoyanbing@mail.ccnu.edu.cn

DOI: 10.1016/S1872-2067(17)62996-6 | http://www.sciencedirect.com/science/journal/18722067 | Chin. J. Catal., Vol. 39, No. 4, April 2018
} 
[12]. Transition metal oxides with impressive low-temperature catalytic activities are considered potential low-cost alternatives to precious metal catalysts $[8,9]$. Among them, copper and its oxides have attracted increasing attention as promising substitutes for precious metals in numerous industrial processes due to their high activities, low cost, and earth-abundant reserves $[13,14]$.

$\mathrm{Cu}$ is a transition metal with a $3 d$ electronic configuration that has some interesting physical and chemical properties. $\mathrm{Cu}$-based materials can promote a variety of reactions, mainly due to their accessible oxidation states $(\mathrm{Cu}(0), \mathrm{Cu}(\mathrm{I})$, and $\mathrm{Cu}(\mathrm{II})$ ). $\mathrm{Cu}$-based oxides are promising materials for broad applications, including catalytic organic transformations, electrocatalysis, and photocatalysis, mainly due to their high redox potential, environmental friendliness, and low cost. For environment remediation, $\mathrm{Cu}$-based oxides have various applications as catalysts, including in the selective catalytic reduction (SCR) of $\mathrm{NO}_{x}$ using $\mathrm{NH}_{3}$, catalytic combustion of VOCs, CO oxidation, organic pollutant degradation, and catalytic oxidation of soot [15]. The catalytic activity of Cu-based catalysts is highly dependent on its material composition, structure, and morphology. Based on the literature, Cu-based catalysts can be generally classified into three types: (i) bulk copper oxide $\left(\mathrm{CuO}_{x}\right)$, (ii) supported copper oxide $\left(\mathrm{CuO}_{x} /\right.$ support), and (iii) solid solution copper oxide $\left(\mathrm{CuO}_{x}-\mathrm{X}\right)$. As reduced use of precious metals is increasingly demanded, much research has focused on the rational fabrication of highly efficient copper oxide catalysts and elucidation of their active catalytic sites. However, reviews dedicated to summarizing recent progress in copper-based catalysts for heterogeneous catalytic reactions used in environmental remediation remain limited.

This review summarizes recent progress toward different $\mathrm{Cu}$-based metal oxides for various typical environment remediation applications, including $\mathrm{CO}$ oxidation, selective $\mathrm{NO}_{x}$ reduction, VOC control, waste water treatment, and soot particulate removal. Herein, we provide insight into the intrinsic relationships between the crystal structure, morphology, catalyst support, and other features of copper oxides and their catalytic performance in specific catalytic reactions for environmental remediation. Furthermore, current obstacles facing towards the broad application of $\mathrm{Cu}$-based catalysts, and potential strategies to address them, have been proposed to potentially shed light on the future research and development of highly efficient $\mathrm{Cu}$-based non-precious metal catalysts.

\section{Structures and properties of $\mathrm{Cu}$-based catalysts}

\subsection{Bulk copper oxide $\left(\mathrm{CuO} \mathrm{O}_{x}\right)$}

Copper oxides $\left(\mathrm{CuO}_{x}\right)$ mainly exist as two stable oxides, namely, cupric oxide $(\mathrm{CuO})$ and cuprous oxide $\left(\mathrm{Cu}_{2} \mathrm{O}\right)$. These $\mathrm{Cu}$-based oxides have various controllable crystal structures, morphologies, porosities, and textures, which contribute to a broad range of adjustable catalytic activities (Fig. 1). These structural parameters play a crucial role in their catalytic oxidation performance. Understanding the relationship between the structure characteristics and catalytic performance of

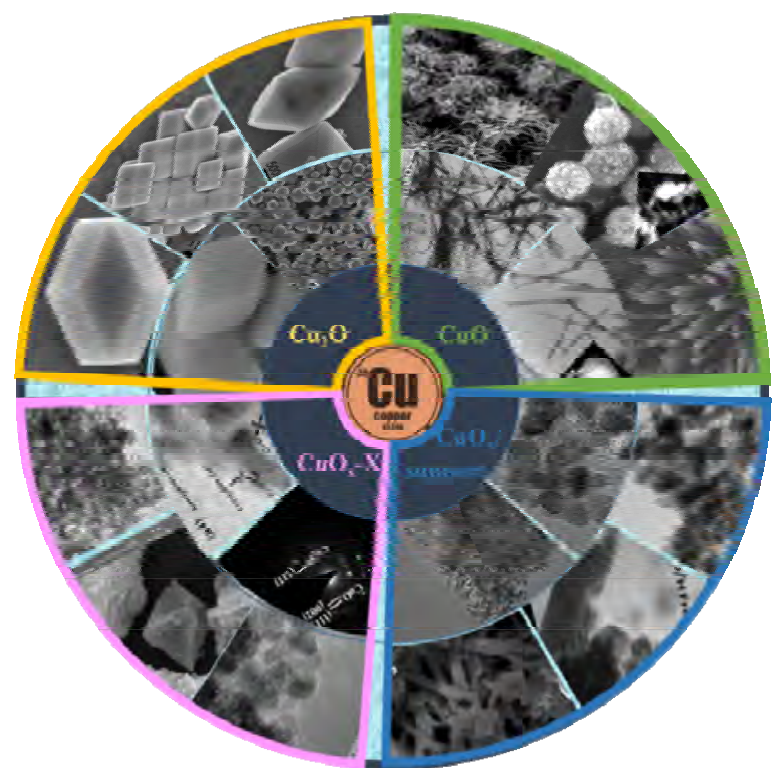

Fig. 1. Structures and morphologies of $\mathrm{Cu}_{2} \mathrm{O}, \mathrm{CuO}$, supported $\mathrm{CuO}_{x}$, and $\mathrm{CuO}_{x}-\mathrm{X}$ catalysts.

Cu-based oxides is the first step in the rational design of high-activity catalysts.

Copper oxides with different valance states often have different catalytic performances in pollutant removal, with catalytic activity originating from one-electron $\left(\mathrm{Cu}^{2+} \leftrightarrow \mathrm{Cu}^{1+}\right.$, $\left.\mathrm{Cu}^{1+\leftrightarrow} \mathrm{Cu}^{0}\right)$ or two-electron $\left(\mathrm{Cu}^{2+\leftrightarrow} \mathrm{Cu}^{0}\right)$ pathways. Furthermore, different morphologies and crystalline structures of $\mathrm{CuO}$ and $\mathrm{Cu}_{2} \mathrm{O}$ lead to different catalytic performances. For example, $\mathrm{CuO}$ mesoporous nanosheets have excellent $\mathrm{CO}$ oxidation catalytic activity shown to be 35 times that of commercial $\mathrm{CuO}$ powders at $200{ }^{\circ} \mathrm{C}$ (up to $47.77 \mathrm{mmol} /(\mathrm{g} \cdot \mathrm{h}$ )) [16]. The large specific surface area, mesoporous structure, low thickness (approx. $10 \mathrm{~nm}$ ), and uniform exposed (002) crystal plane of these nanosheets are responsible for their increased active sites and simultaneous dramatic enhancement in activity $[17,18]$. The (002) plane of $\mathrm{CuO}$ nanosheets, terminated with an atomic $\mathrm{Cu}$ layer that gives rise to insufficient oxygen atoms coordinating with $\mathrm{Cu}$ atoms on the surface, is a close-packed plane with more dangling bonds that could potentially adsorb more CO gas. Furthermore, the lack of coordination between oxygen atoms and $\mathrm{Cu}$ atoms on the surface of the as-prepared $\mathrm{CuO}$ nanosheets also enhanced their catalytic activity [19]. Recent studies have developed novel synthetic methods, such as metal-organic chemical vapor deposition (MOCVD), laser ablation, hydrothermal processing, thermal oxidation, and the wet chemical method, to control the morphology and enhance catalytic performance [20].

Copper oxides in the form of cuprous oxide $\left(\mathrm{Cu}_{2} \mathrm{O}\right)$ and cupric oxide $(\mathrm{CuO})$ are p-type semiconductors with relatively low direct band gaps of $\sim 2$ and $\sim 1.2 \mathrm{eV}$, respectively [21]. Much effort has been dedicated to adjusting the synthetic conditions for obtaining copper oxides $\left(\mathrm{CuO}_{x}\right)$ with desirable shapes, sizes, morphologies, and crystal structures to improve their catalytic performance [22]. $\mathrm{Cu}_{2} \mathrm{O}$ has a face-centered cubic $(f c c)$ crystal structure (space group, $O^{4} K^{-} p n 3 m$ ), in which oxygen atoms form 
a body-centered cubic lattice and copper atoms form a face-centered cubic lattice with a unit cell length of $4.27 \AA$, that is the active component of catalysts used for CO oxidation and VOC combustion. The optimized surface structures of low-index $\mathrm{Cu}_{2} \mathrm{O}$ (100), $\mathrm{Cu}_{2} \mathrm{O}$ (110), and $\mathrm{Cu}_{2} \mathrm{O}$ (111) crystal planes have surface energies in the order $(100)<(110)<(111)$ $[11,12]$. Numerous $\mathrm{Cu}_{2} \mathrm{O}$ nano- and microstructures with well-controlled uniform morphologies have recently been synthesized, including (111) octahedra [23], (100) cubes [24], (100) truncated octahedra [25], rhombic dodecahedra [26], (110) truncated octahedra, (100) truncated rhombic dodecahedra, nanowires, nanoplates, nanocages, and branched and hollow structures. On $\mathrm{Cu}_{2} \mathrm{O}$ (100), the topmost layer consists of two-coordinated $\mathrm{O}$ and $\mathrm{Cu}$ atoms on the surface that are coordinatively saturated. $\mathrm{On} \mathrm{Cu}_{2} \mathrm{O}(110)$, the topmost layer consists of three-coordinated $\mathrm{O}$ and $\mathrm{Cu}$ atoms, while the second layer consists of $\mathrm{Cu}$. The $\mathrm{Cu}_{2} \mathrm{O}(100)$ surface is more stable than the $\mathrm{Cu}_{2} \mathrm{O}$ (111) surface due to the terminated coordinated $\mathrm{Cu}$ atoms with abundant d-electrons on the $\mathrm{Cu}_{2} \mathrm{O}$ (111) surface. On $\mathrm{Cu}_{2} \mathrm{O}$ (111), the topmost layer consists of three-coordinated $\mathrm{O}$ and the second layer consists of $\mathrm{Cu}$ (75\%) and singly-coordinated unsaturated $\mathrm{Cu}(25 \%)$. $\mathrm{Cu}$ atoms on the (111) surface are usually coordinatively unsaturated with more dangling bonds for the adsorption of ionized oxygen species, which are responsible for the high activity [27]. $\mathrm{CuO}$ is a semiconducting oxide that crystallizes in the complex monoclinic tenorite structure with $\mathrm{Cu}-\mathrm{O}$ planes. Several different $\mathrm{CuO}$ morphologies, such as nanowires [28], nanotubes [29], ribbons [30], flower shapes [31], nanorings [28], and hollow microspheres [32], can be fabricated under different synthetic conditions. The close-packed low-index (111) planes of the oxides have lower free energies and higher stabilities than the more open (001) and (011) planes. The reactivity on the crystal surfaces is correlated with the surface energy, which had an observable effect on the oxygen chemisorption energy at $\mathrm{CuO}$ surfaces. Furthermore, high-index planes of $\mathrm{CuO}_{x}$ nanomaterials are terminated by an atomic $\mathrm{Cu}$ layer, which gives rise to coordinatively unsaturated $\mathrm{Cu}$ atoms on the surface. In addition, the close-packed plane with more dangling bonds could potentially adsorb more CO gas [19].

\subsection{Supported copper oxide ( $\mathrm{CuO} \mathrm{O}_{x} /$ support)}

Supported copper oxide $\left(\mathrm{CuO}_{x} /\right.$ support $)$, typically comprising $\mathrm{CuO}_{x}$ primary active sites and a high surface area support, such as $\mathrm{CeO}_{2}$ and zeolite, is a common composite catalyst with enhanced performance in various heterogeneous catalytic reactions. Generally, these supports have multiple roles. First, the support enlarges the surface area available for $\mathrm{CuO}_{x}$ active sites. The catalyst support provides a very large surface area over which active sites are dispersed efficiently, which can prevent particle aggregation and the associated degradation in catalytic activity. Furthermore, the catalyst support can provide space for the catalytic reaction to occur. For example, activated carbon is often used as a catalyst support to provide space for active sites and the catalytic reaction [33]. Second, the supports can improve the catalytic properties of the composite catalyst by participating in the reaction via promoting charge transfer or the $\mathrm{O}_{2}$ storage capacity [34]. $\mathrm{CeO}_{2}$ can enhance $\mathrm{O}_{2}$ storage performance, which is beneficial for gaseous pollutant adsorption and catalytic oxidation. Third, due to a synergy effect, the interface between the catalyst and support may contain new active sites for the efficient absorption of molecular reactants or favor fast charge transfer, with the reversible oxidation capability then further enhancing the intrinsic catalytic activity of the composite catalysts. For instance, the quick reversible redox process of superficial $\mathrm{Cu}(\mathrm{I}) /(\mathrm{II})$ couples in a strong synergistic interaction with a nanocrystalline ceria support at the interface between the active $\mathrm{Cu}$ sites and ceria is responsible for its low-temperature catalytic activity.

According to the literature, supports that have been used with $\mathrm{CuO}_{x}$ include $\mathrm{Al}_{2} \mathrm{O}_{3}, \mathrm{CeO}_{2}$, and $\mathrm{Ce}-\mathrm{Zr}$ solid solutions. These catalytic supports can be classified into two categories: inert supports and functional supports. Inert supports, such as $\mathrm{Al}_{2} \mathrm{O}_{3}$ [35] and zeolites [36], do not take part in the catalytic reaction and only supply space for the catalytic reaction or improve the dispersion of $\mathrm{CuO}_{x}$ particles. In contrast, functional catalyst supports, such as $\mathrm{CeO}_{2}$ [37] and Ce-Zr solid solutions [38], often act as adsorption sites for the reaction. The unique ability of $\mathrm{Ce}^{4+} / \mathrm{Ce}^{3+}$ and ensuing oxygen vacancy generation are key factors in its application to heterogeneous catalysis. Compared with $\mathrm{CeO}_{2}$, Ce- $\mathrm{Zr}$ solid solutions can better enhance $\mathrm{O}_{2}$ storage performance, which makes Ce-Zr solid solution the most used non-carbon catalytic support in various catalytic reactions. Although many different catalyst supports have been reported, their basic function remains promoting the high dispersion of active $\mathrm{Cu}$ sites on composite catalysts.

\subsection{Solid solution copper oxides $\left(\mathrm{CuO} \mathrm{O}^{-}-\mathrm{X}\right)$}

Solid solution metal oxide $\left(\mathrm{CuO}_{x}-\mathrm{X}\right)$ catalysts are of great interest due to their modifying effects on copper oxides, which can enhance the thermodynamic stability, electronic properties, and surface properties. These modifying elements are mainly transition metal elements and rare earth elements. Most transition metal oxides, such as $\mathrm{TiO}_{2}, \mathrm{MnO}_{x}$, and $\mathrm{CoO}_{x}$, also show catalytic performance for pollutants. Composites of $\mathrm{CuO}_{x}$ and these transition metal oxides could synergistically enhance the catalytic performance of the system. In general, $\mathrm{CuO}$ often suffers from $\mathrm{SO}_{2}$ poisoning and low reactivity at high temperatures. With the addition of transition metal oxides, $\mathrm{Ti}^{-} \mathrm{CuO}_{x}$ can protect $\mathrm{CuO}$ from $\mathrm{SO}_{2}$ poisoning [39]. In many cases, $\mathrm{CuO}$ has a higher catalytic performance at low temperature. Moreover, with the addition of $\mathrm{FeO}_{x}[40,41]$ or $\mathrm{CoO}_{x}$ [42], the high-temperature activity can be enhanced. Some main group elements, such as $\mathrm{Zr}$ [43] and Sn [44], have commonly been used to modify $\mathrm{CuO}$. Both these oxides have nearly no activity in catalytic reactions. However, the incorporation of main group elements into $\mathrm{CuO}_{x}$ enhances the properties of $\mathrm{CuO} . \mathrm{CeO}_{2}$ has excellent oxygen storage performance and can capture gaseous $\mathrm{O}_{2}$ from flue gas to form adsorbed oxygen, which means it could offer suitable adsorption sites for gaseous pollutants. Recently, ternary composite oxides and multicomposite oxides have been developed to further enhance the performance of $\mathrm{CuO}$. A ter- 
nary mixed oxide catalyst composed of copper oxide, cobalt oxide, and ceria showed superior catalytic performance in $\mathrm{CO}$ oxidation [45]. The ability to separate the active sites of $\mathrm{CO}$ and hydrocarbons $\left(\mathrm{CH}_{x}\right)$ might drastically reduce the inhibition effects. Understanding the role of each element and the interaction of these elements is beneficial for the rational design of highly efficient $\mathrm{Cu}$-based catalysts. Furthermore, element doping in copper oxides could change the local charge conditions and enhance sulfur resistance [46], propene resistant [45], and the low-temperature catalytic activity [47].

\section{Copper-based catalysts for gas phase pollutant control}

\subsection{Recent advances in copper-based catalysts for CO oxidation}

Carbon monoxide is usually generated by the incomplete combustion of fossil fuels [48]. Copper oxides, such as $\mathrm{Cu}_{2} \mathrm{O}$ and $\mathrm{CuO}$, are known to exhibit high activities in the oxidation of $\mathrm{CO}$. Huang et al. [49] investigated the catalytic combustion performance of $\mathrm{CO}$ over copper oxide catalysts $\left(\mathrm{Cu}_{2} \mathrm{O}\right.$ and $\left.\mathrm{CuO}\right)$. The results indicated that their catalytic activities were in the order $\mathrm{Cu}_{2} \mathrm{O}>$ metastable cluster $\mathrm{CuO}>\mathrm{CuO}$, which correlated with valence variations and the ability to seize or release the surface lattice [50]. Compared with fresh $\mathrm{Cu}_{2} \mathrm{O}$ catalysts, the higher surface concentration of active chemisorbed oxygen and corresponding improved interaction with $\mathrm{CO}$ contributed to the dramatically enhanced activity on the samples used [51]. The shape and exposed crystal planes have been shown to play an important role in the catalytic oxidation of CO. Surface oxygen vacancies, generated by coordinately unsaturated $\mathrm{Cu}$ atoms on the surface, can adsorb ionized oxygen species and react with the reducing gas more readily. Truncated concave octahedral $\mathrm{Cu}_{2} \mathrm{O}$ enclosed mainly by (332) high-index facets exhibited enhanced catalytic activity compared with low index (111) and (100) facets, which could be due to the presence of high-density steps on the (332) high-index facets. The CO catalytic activities of the crystal facets were found to be in the order (332) > (111) > (100) [22]. Similar facet-dependent CO oxidation catalytic activity has also been observed on $\mathrm{CuO} . \mathrm{CuO}$ nanoplatelets with exposed (011) planes more easily release oxygen from the surface lattice, followed by nanobelts with (001) planes, which, in turn, are more active than nanoparticles with close-packed (111) planes [52]. As morphologies play an important role in determining the properties of nanostructured materials, Huang et al. [19] devoted much effort to engineer the morphologies of $\mathrm{CuO}$ nanostructures and synthesize nanosheets with high-index (002) facets exposed, as shown in Fig. 2(a) and (b). The catalytic activity of these $\mathrm{CuO}$ mesoporous nanosheets in CO oxidation was found to be up to 47.77 $\mathrm{mmol} /(\mathrm{g} \cdot \mathrm{h})$, which is about 35 times higher than that of commercial $\mathrm{CuO}$ powders at $200{ }^{\circ} \mathrm{C}$, (Fig. 2(c)). As shown in Fig. $2(\mathrm{~d})$, the low apparent activation energy $(53.3 \mathrm{~kJ} / \mathrm{mol})$ of the
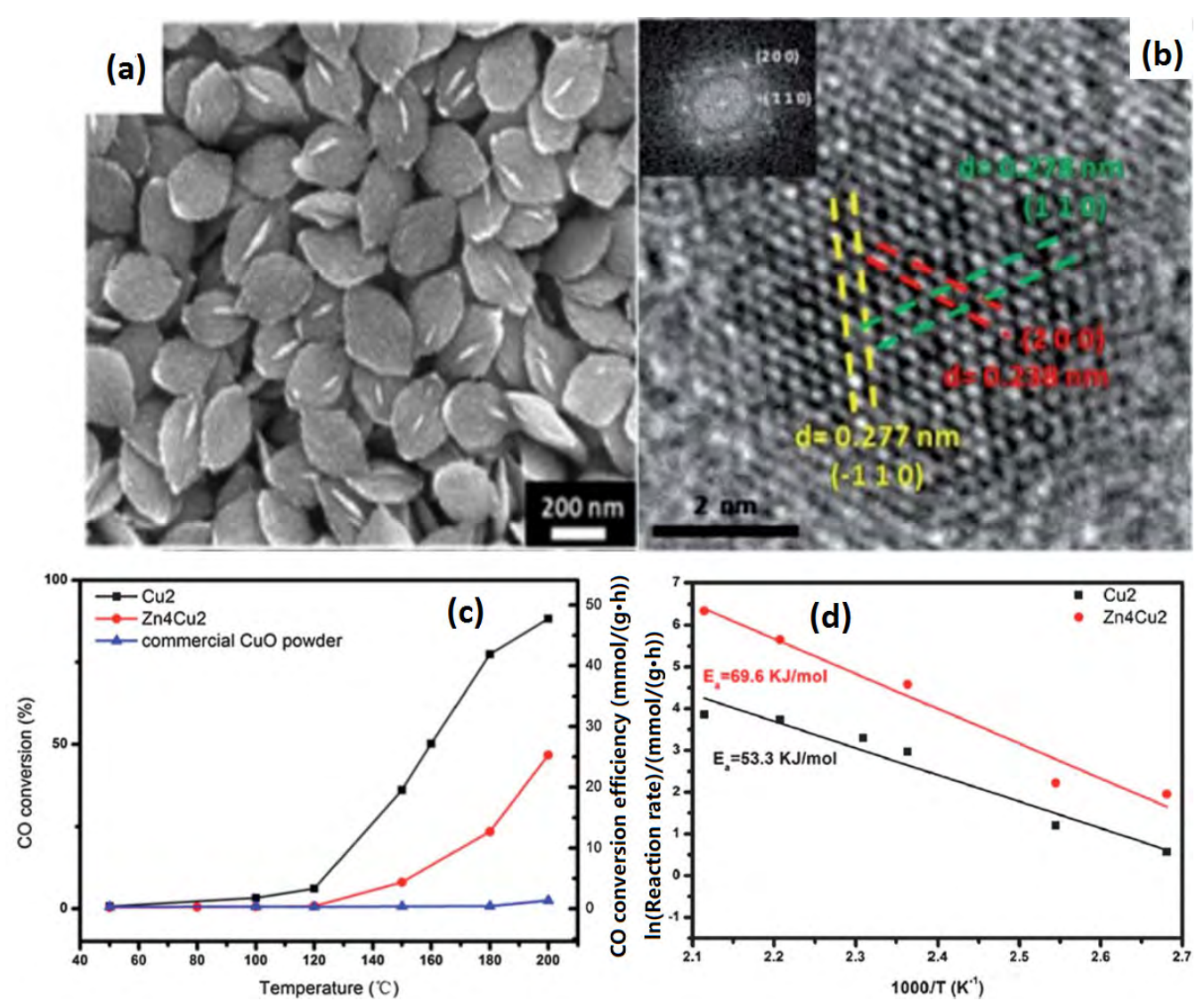

Fig. 2. (a) Scanning electron microscopy (SEM) and (b) high-resolution transmission electron microscopy (HRTEM) images of a CuO nanosheet; (c) $\mathrm{CO}$ oxidation conversion light-off curves using $\mathrm{CuO}$ nanosheets; (d) Arrhenius plots for the reaction activation energy $\left(E_{\mathrm{a}}\right)$ on $\mathrm{CuO}$ nanosheets and Zn4Cu2 nanoparticles. Adapted from Ref. [19]. 
$\mathrm{CuO}$ nanosheets further evidenced the high catalytic activity for CO oxidation. The exposed crystal plane was assigned to the (002) crystal plane of the $\mathrm{CuO}$ nanosheet, which was vital to its superior catalytic performance because of the terminated coordinatively unsaturated atomic $\mathrm{Cu}$ layer on the surface. The close-packed plane with more dangling bonds could possibly adsorb more $\mathrm{CO}$ gas. Furthermore, the lack of oxygen atoms coordinated to $\mathrm{Cu}$ atoms on the surface of this $\mathrm{CuO}$ nanosheet could also enhance its catalytic activity [19].

Copper-manganese oxides supported on multiwalled carbon nanotubes (MWCNTs) have been synthesized as efficient catalysts for low-temperature $\mathrm{CO}$ oxidation [53]. The temperature for total CO conversion $\left(\mathrm{T}_{100}\right)$ on these catalysts was $200^{\circ} \mathrm{C}$ and the half-conversion temperature $\left(\mathrm{T}_{50}\right)$ was stable at $63-70{ }^{\circ} \mathrm{C}$, which was much lower for $\mathrm{CuO}-\mathrm{MnO}_{2}$ bimetallic catalysts with half CO conversions of 83.9-196.4 ${ }^{\circ} \mathrm{C}$. The synergistic interaction within the bimetallic $\mathrm{Cu}-\mathrm{Mn}$ catalytic system, high surface area, and large pore volume are responsible for its enhanced activity for CO oxidation.

Since the groundbreaking work of Flytzani-Stephanopoulos et al. [54], regarding the catalytic oxidation of CO using even physical mixtures of $\mathrm{CuO}$ and $\mathrm{CeO}_{2}$ as catalyst, low-temperature $\mathrm{CO}$ oxidation mediated by $\mathrm{CuO} / \mathrm{CeO}_{2}$ catalysts has been extensively investigated. $\mathrm{CeO}_{2}$ in contact with $\mathrm{Cu}^{2+}$ facilitates the formation of $\mathrm{Cu}^{+}$due to the $\mathrm{Ce}^{4+} / \mathrm{Ce}^{3+}$ redox process, which can transfer electrons to $\mathrm{Cu}^{2+}$ to form $\mathrm{Cu}^{+}$. This enhances $\mathrm{CO}$ adsorption, leading to the excellent catalytic activity [55-59]. Solid-solution $\mathrm{Cu}_{y} \mathrm{Ce}_{1-y} \mathrm{O}_{2-x}$ and mixed-phase $\mathrm{CuO} / \mathrm{Cu}_{y} \mathrm{Ce}_{1-y} \mathrm{O}_{2-x}$ catalysts are particularly promising for $\mathrm{CO}$ oxidation under ambient conditions, $\mathrm{Cu}_{0.1} \mathrm{Ce}_{0.9} \mathrm{O}_{2-x}$ exhibited the highest activity among catalysts measured, with a computed oxygen vacancy formation energy $\left(E_{\mathrm{vac}}\right)$ of $0.85 \mathrm{eV}$ [59]. In contrast, $\mathrm{CuO} / \mathrm{Cu}_{0.05} \mathrm{Ce}_{0.95} \mathrm{O}_{2-x}$ catalyst showed a $\mathrm{CO}$ oxidation rate of 0.2 $\mu \mathrm{mol} /(\mathrm{s} \cdot \mathrm{g})$ at $45^{\circ} \mathrm{C}$, making it the most active $\mathrm{CuO}_{x} / \mathrm{CeO}_{2}$ composite catalyst among those reported [60]. To further understand the generally recognized synergetic effects in $\mathrm{CuO}-\mathrm{CeO}_{2}$ catalysts, Luo et al. [61] concluded that finely dispersed species possessed the highest activity, bulk $\mathrm{CuO}$ species had medium activity, while $\mathrm{Cu}^{2+}$ in the $\mathrm{CeO}_{2}$ lattice had the lowest activity. $\mathrm{Cu}$-Ce mixed oxides prepared by microemulsion-coprecipitation showed better catalytic performance than that prepared by an impregnation method due to structure related activity in nanostructured copper-ceria-based CO oxidation catalysts.
When doped with $\mathrm{Cu}^{2+}$, markedly improved catalysis is observed owing to homogeneous incorporation of $\mathrm{Cu}^{2+}$ into the $\mathrm{CeO}_{2}$ lattice. The $\mathrm{T}_{50}$ values for $\mathrm{CO}$ using $\mathrm{Cu}_{0.1} \mathrm{Ce}_{0.9 \mathrm{O}_{2-\delta}}$ and $\mathrm{Cu}_{0.04} \mathrm{Ce}_{0.96} \mathrm{O}_{2-\delta}$ were 83 and $95{ }^{\circ} \mathrm{C}$, respectively [62-64]. The superior catalytic activity of the $\mathrm{CuO}_{x} / \mathrm{CeO}_{2}$ catalyst system in CO oxidation at low temperatures can be attributed to the quick reversible redox process of superficial $\mathrm{Cu}(\mathrm{I}) /(\mathrm{II})$ couples in a strong synergistic interaction with the nanocrystalline ceria support [65]. Copper ions migrate out of the $\mathrm{CeO}_{2}$ crystallite and aggregate on the $\mathrm{CeO}_{2}$ surface, which results in a lower coordination environment that enhances the reducibility of $\mathrm{Ce}^{4+} / \mathrm{Ce}^{3+}$. In Scheme $1(\mathrm{a})$, steps I and II illustrate the reaction mechanism of $\mathrm{CO}$ oxidation over bulk $\mathrm{CuO}$, in which $\mathrm{CO}_{2}$ is generated from the oxidation of $\mathrm{CO}$ by $\mathrm{Cu}(\mathrm{II})$, resulting in the formation of a $\mathrm{Cu}(\mathrm{I})$ species, which is oxidized by $\mathrm{O}_{2}$ to complete the catalytic cycle. Steps III and IV describe the role $\mathrm{Ce}^{4+} / \mathrm{Ce}^{3+}$ ion pairs play in the reaction. The reduced $\mathrm{Cu}$ species (CuI) are reoxidized at the $\mathrm{Cu} / \mathrm{CeO}_{2}$ interface by $\mathrm{CeO}_{2}$-mediated oxygen transport and form oxygen vacancies that can be filled by adsorbed $\mathrm{O}_{2}$ to complete the recycle. This redox cycle promotes the ability of copper ions to adopt different oxidation states and supply oxygen [37]. The redox relationship between copper and cerium in the catalyst is key to understanding the reaction mechanism and improving the catalytic performance [58]. Scheme 1 (b) shows the $\mathrm{CO}$ oxidation mechanism on $\mathrm{Cu}_{2} \mathrm{O}$, which suggests that $\mathrm{Cu}_{2} \mathrm{O}$ is more active for $\mathrm{CO}$ oxidation than $\mathrm{Cu}(111)$ due to the higher $\mathrm{CO}$ adsorption energy on $\mathrm{Cu}_{2} \mathrm{O}$. This inhibits oxygen poisoning because of the significant difference between $\mathrm{CO}$ and $\mathrm{O}$ adsorption energies [66].

Although $\mathrm{Cu}_{2} \mathrm{O}$ has superior $\mathrm{CO}$ oxidation activity at low temperatures, poor thermal and hydrothermal stability are the main obstacles to its broad industrial application. To understand how to stabilize the $\mathrm{CuO}_{x}$, Baber et al. [67] fabricated $\mathrm{TiCuO}_{x}$ films by depositing titanium onto a $\mathrm{Cu}_{2} \mathrm{O}(111)$ film at $300 \mathrm{~K}$. The as-prepared $\mathrm{TiCuO}_{x}$ film exhibited excellent lowtemperature activity and stability in $\mathrm{CO}$ oxidation, as shown in Fig. 3(b). An atomically resolved scanning tunneling microscopy (STM) image of a hexagonal island (Fig. 3(a)) exhibited a Moire structure $(1.82 \pm 0.15 \mathrm{~nm})$ and a close-packed hexagonal structure $(0.28 \pm 0.02 \mathrm{~nm})$. Density functional theory (DFT) calculations are presented in Fig. 3(b) and (d), in which most of the copper atoms located on the surface have separated by long distances of $0.894 \mathrm{~nm}$. The long distance between each surface
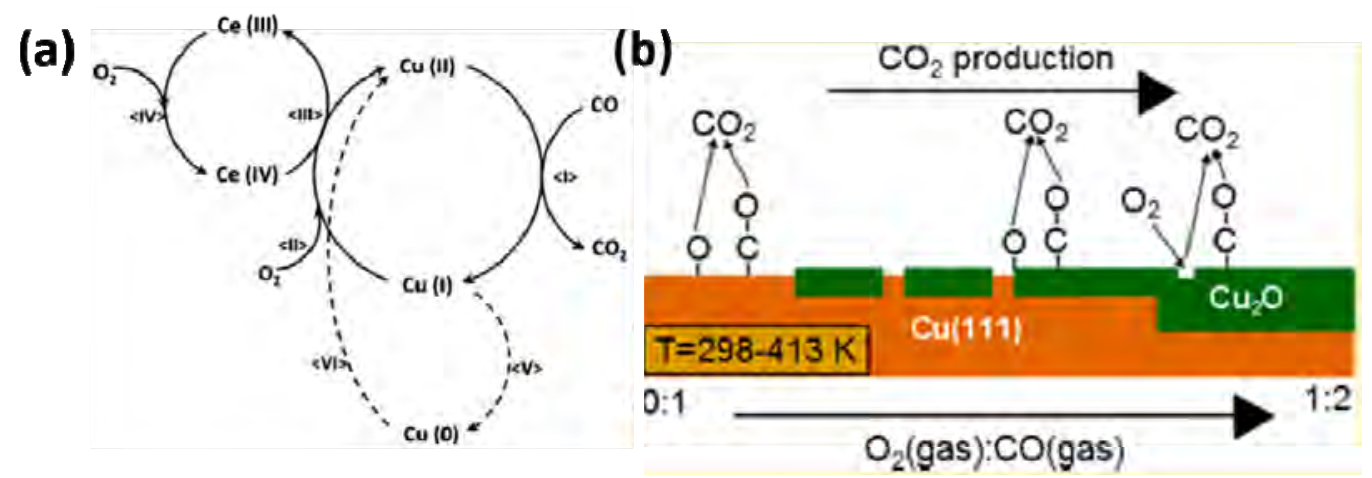

Scheme 1. Proposed mechanism for $\mathrm{CO}$ oxidation over (a) $\mathrm{CuO} / \mathrm{CeO}_{2}$ (adapted from Ref. [58]) and (b) $\mathrm{Cu}_{2} \mathrm{O}$ (adapted from Ref. [66]). 

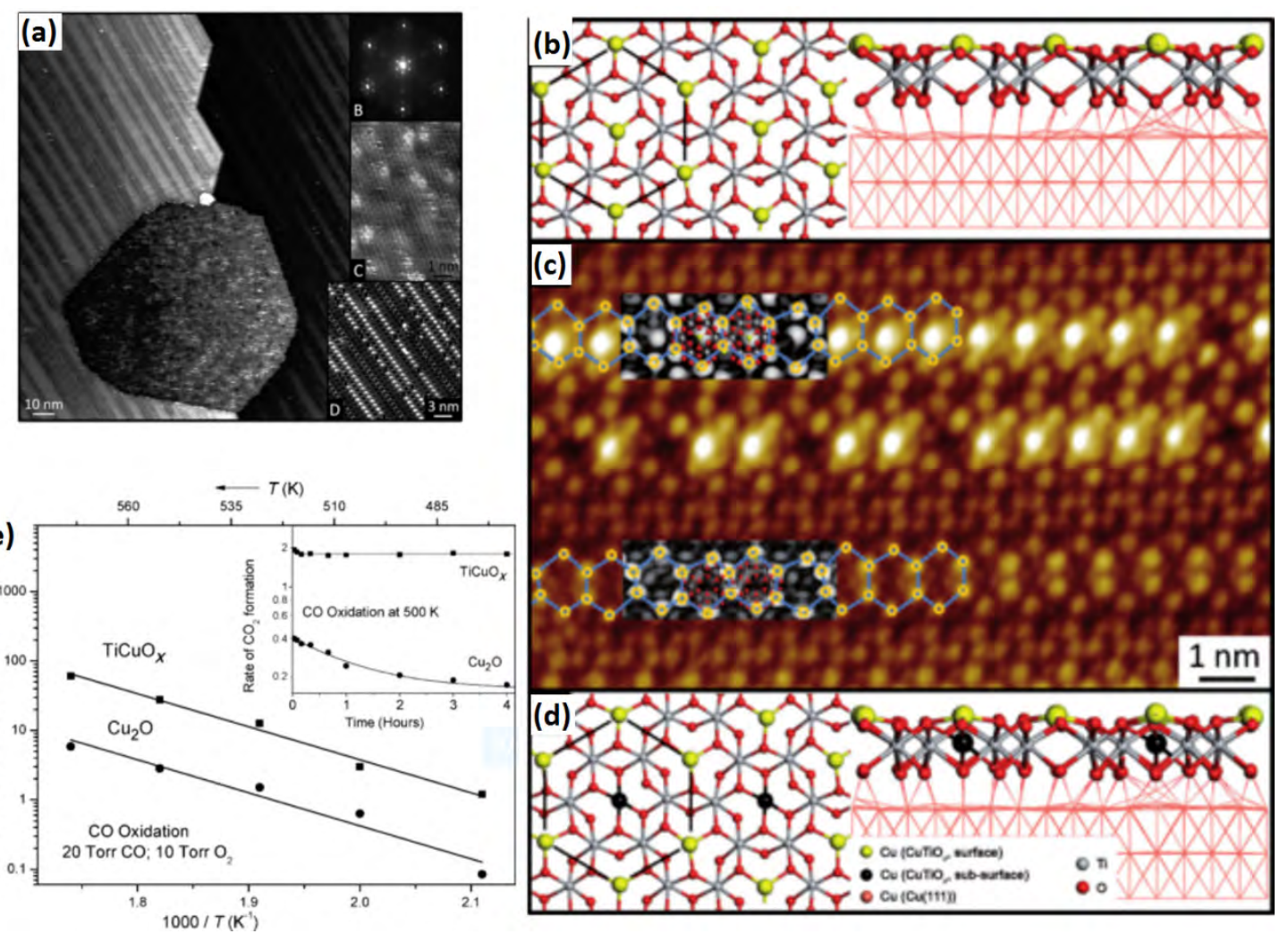

Fig. 3. (a) Scanning tunneling microscopy (STM) images and low-energy electron diffraction (LEED) pattern of a TiCuO $\mathrm{O}_{x}$ film; (b-d) Comparison of structures predicted by density functional theory (DFT) calculations with an $\mathrm{STM}^{2}$ image of $\mathrm{TiCuO}_{x}$ terraces; (e) Arrhenius plot of $\mathrm{CO}$ oxidation on $\mathrm{Cu}_{2} \mathrm{O}$ and $\mathrm{TiCuO}_{x}$ films. Adapted from Ref. [67].

$\mathrm{Cu}^{+}$cations in the mixed oxide inhibits facile dissociation of the adsorbed oxygen molecules, which prevents further oxidation of $\mathrm{Cu}^{+}$active sites to $\mathrm{Cu}^{2+}$. DFT calculations was used to determine the complex catalytic behavior of $\mathrm{CuTiO}_{x}$ mixed oxides during $\mathrm{CO}$ oxidation [68]. The $\mathrm{Cu}^{+}$ions were separated by the structural frame of $\mathrm{TiO}_{x}$ and the strong interaction (electronic effect) at $-\mathrm{Cu}-\mathrm{O}-\mathrm{Ti}-$ interfacial sites led to the reduction of $\mathrm{Ti}^{\delta+}$, which enhanced activity toward $\mathrm{O}_{2}$. The unique structural frame of $\mathrm{CuTiO}_{x}$ was able to stabilize and isolate a single $\mathrm{Cu}^{+}$ site on the terrace, which was proposed to be active for $\mathrm{CO}$ oxidation.

Copper oxide-based catalysts, such as hopcalite $\left(\mathrm{CuMn}_{2} \mathrm{O}_{4}\right)$, are among the most active catalysts for low-temperature CO oxidation. Recently, Tang et al. [69] synthesized nanocrystalline copper manganese oxide catalysts using the supercritical antisolvent precipitation method that showed catalytic activity more than two times higher than conventionally prepared hopcalite catalysts for $\mathrm{CO}$ oxidation [70]. They attributed this high catalytic activity to the nanocrystalline and homogeneous nature of the synthesized copper manganese oxides.

A ternary mixed oxide catalyst composed of copper oxide, cobalt oxide, and ceria (denoted CCC) outperforms synthesized and commercial platinum group metal (PGM) catalysts for $\mathrm{CO}$ oxidation in simulated exhaust streams, while showing no sign of inhibition by propene [45]. The enrichment of $\mathrm{Cu}^{+}$on the surface of $\mathrm{CuO}-\mathrm{Co}_{3} \mathrm{O}_{4}-\mathrm{CeO}_{2}$, resulting in a stronger interaction between $\mathrm{Co}_{3} \mathrm{O}_{4}$ and $\mathrm{CeO}_{2}$ and the appearance of oxygen vacan- cies in $\mathrm{CeO}_{2}$, afforded higher catalytic activity in $\mathrm{CO}$ oxidation compared with catalysts heated at different temperatures [71]. $\mathrm{Cu}^{+}$ions are proposed to be active sites and form $\mathrm{Cu}^{+}-\mathrm{CO}$ species, while lattice oxygen located at the $\mathrm{Co}_{3} \mathrm{O}_{4}-\mathrm{CeO}_{2}$ interface is proposed to be the origin of active oxygen [72].

\subsection{Selective catalytic reduction (SCR) of $\mathrm{NO}_{x}$ using $\mathrm{NH}_{3}$}

The abatement of environmentally harmful $\mathrm{NO}_{x}$ compounds ( $\mathrm{NO}, \mathrm{NO}_{2}$, and $\mathrm{N}_{2} \mathrm{O}$ ) emitted from mobile and stationary power sources remains a challenging task in the field of catalysis. The removal of nitrogen oxides $\left(\mathrm{NO}_{x}\right)$ has received more attention in past decades because $\mathrm{NO}_{x}$ are known to cause many environmental problems, including acid rain and photochemical smog in urban and industrial areas $[17,73]$. The selective catalytic reduction (SCR) of $\mathrm{NO}_{x}$ using ammonia has been the subject of extensive research [74]. The basic SCR reaction can be described as follows $4 \mathrm{NH}_{3}+4 \mathrm{NO}+\mathrm{O}_{2} \rightarrow 4 \mathrm{~N}_{2}+6 \mathrm{H}_{2} \mathrm{O}$.

$\mathrm{V}_{2} \mathrm{O}_{5}-\mathrm{WO}_{3} / \mathrm{TiO}_{2}$ is the traditional catalyst for the commercial SCR of $\mathrm{NO}_{x}$ using ammonia ( $\left.\mathrm{NH}_{3}-\mathrm{SCR}\right)$. However, its drawbacks, including a narrow working temperature range, the use of toxic vanadium species, and low $\mathrm{N}_{2}$ selectivity at high temperatures [75], have motivated a new wave of innovation toward more efficient and environmentally friendly alternative catalysts for $\mathrm{NH}_{3}$-SCR-NO ${ }_{x}$. Among various attempts, copper-based catalysts supported on oxides or zeolites have recently emerged as attractive candidates due to their environmentally benign char- 
acteristics and high SCR performance in a wide temperature range with good selectivity $[76,77]$.

Supported copper oxides fabricated by dispersing active $\mathrm{Cu}$ species on large surface area supports have been widely studied in $\mathrm{NH}_{3}$-SCR catalysis. Molecular sieves (such as zeolites, ZSM-5, SBA-15, and SSZ-13), Ce-Zr solid solutions, and metal oxides (such as V-based oxides, $\mathrm{TiO}_{2}$, and $\mathrm{Ce}-\mathrm{TiO}_{2}$ ) are widely used as supports. Molecular sieves have complex structures with microporous-mesoporous characteristics and specific surface properties responsible for enhancing catalytic performance and thermal stability [77,78]. Cu-promoted zeolites, such as Cu-ZSM-5, Cu-BEA, and Cu-FER, have shown superior low-temperature $\left(<300{ }^{\circ} \mathrm{C}\right)$ conversion and selectivity in $\mathrm{NH}_{3}$-SCR and direct NO decomposition. Iwamoto et al. [80] synthesized a series of metal $(\mathrm{Zn}, \mathrm{Mg}, \mathrm{Co}$, and $\mathrm{Cu}$ ) oxides on a ZSM-5 support, among which $\mathrm{Cu}^{2+-}$ exchanged zeolites appeared to be more active for NO decomposition. The high dispersion of $\mathrm{CuO}$ and high surface acidity of the catalyst were found to be responsible for the high de- $\mathrm{NO}_{x}$ performance. Compared with $\mathrm{Cu}-\mathrm{ZSM}-5$ catalysts, a $\mathrm{Cu}^{2+}$ ion-exchanged beta zeolite (Cu-beta) has been shown to have higher activity in the SCR of $\mathrm{NO}_{x}$ using $\mathrm{NH}_{3}$, with metal-exchanged beta zeolites generally found to have improved hydrothermal stability. The en- hanced catalytic performance is due to the higher copper valence and lattice oxygen mobility compared with the $\mathrm{Cu} / \mathrm{ZSM}-5$ catalyst [81]. Having met the activity and durability requirements of the automotive industry, $\mathrm{Cu}^{2+-}$ exchanged molecular sieves with chabazite (CHA) structures, such as Cu-SSZ-13 and $\mathrm{Cu}-\mathrm{SAPO}-34$, have been commercialized as $\mathrm{NO}_{x}$ after-treatment catalysts in diesel-powered engines for transportation. SSZ-13 is appropriate for use in the SCR of NO using $\mathrm{NH}_{3}$ due to its adjustable pore diameter, thick pore walls, and excellent hydrothermal stability $[60,82]$. As shown in Fig. 4(a), the $\mathrm{NO}_{x}$ conversions of these catalysts in the high-temperature region $\left(350-550{ }^{\circ} \mathrm{C}\right)$ were in the order Cu-SSZ-13 > Cu-ZSM-5 > $\mathrm{Cu}$-beta. At reaction temperatures above $300{ }^{\circ} \mathrm{C}, \mathrm{Cu}-\mathrm{ZSM}-5$ and $\mathrm{Cu}$-beta produced significant amounts of $\mathrm{NO}_{2}$ and $\mathrm{N}_{2} \mathrm{O}$, while at $500{ }^{\circ} \mathrm{C}$ the amounts of $\mathrm{NO}_{2}$ and $\mathrm{N}_{2} \mathrm{O}$ produced over these two catalysts were 30 and $25 \mathrm{ppm}$, respectively, which was much higher than the $<10$ ppm measured over Cu-SSZ-13 (Fig. 4(b) and (c)). As shown in Fig. 4(d), Cu-SSZ-13 has the best resistance toward $\mathrm{SO}_{2}$ and $\mathrm{C}_{3} \mathrm{H}_{6}$ poisoning. The pore size of SSZ-13 (3.8 ̊) was smaller than the kinetic diameter of $\mathrm{C}_{3} \mathrm{H}_{6}$ (4.678 $\AA$ ), which provided a size restriction for gaseous molecules. Therefore, active sites located inside the channel can still operate without being affected by $\mathrm{C}_{3} \mathrm{H}_{6}$ introduction $[83,85]$.
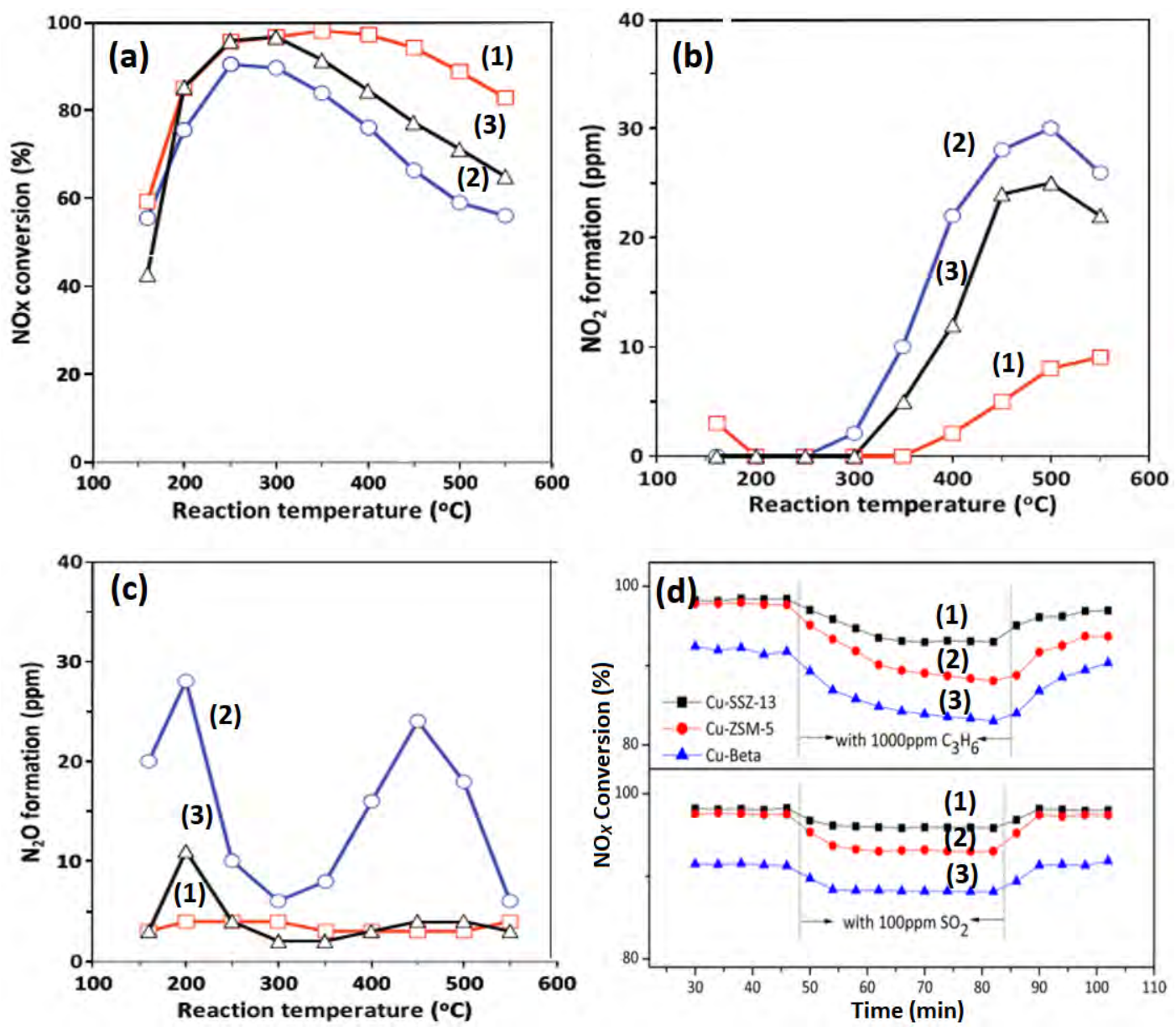

Fig. 4. (a) $\mathrm{NO}_{x}$ conversion profiles for Cu-SSZ-13 (1), Cu-beta (2), and Cu- ZSM-5 (3) at various temperatures; (b) $\mathrm{NO}_{2}$ and (c) $\mathrm{N}_{2} \mathrm{O}$ formation profiles during $\mathrm{NH}_{3}$-SCR on Cu-SSZ-13 (1), Cu-beta (2), and Cu-ZSM-5 (3), adapted from Ref. [78]; (d) $\mathrm{NO}_{x}$ conversion of Cu-zeolites (Cu-SSZ-13 (1), Cu- ZSM-5 (2), Cu-beta (3)) with $\mathrm{C}_{3} \mathrm{H}_{6}$ and $\mathrm{SO}_{2}$, adapted from Ref. [79]. 
SSZ-13 exhibits the highest $\mathrm{SO}_{2}$ to $\mathrm{SO}_{3}$ conversion, hindering the generation of more stable $\mathrm{CuSO}_{4}$, which could cause serious deactivation. At least three $\mathrm{NH}_{3}$ adsorption sites, including two distinct populations of exchanged $\mathrm{Cu}$ sites and Brönsted acid sites, have been identified in $\mathrm{Cu}-\mathrm{SSZ}-13$, and are responsible for the enhanced catalytic performance [84]. The differences in activity and selectivity of the three zeolites above may be related to the fundamental structural characteristic of these zeolites, namely, the pore sizes and locations of the copper ions. The order of high-temperature $\mathrm{NH}_{3}$-SCR reactivity discussed earlier was the inverse of the zeolite pore size order. SSZ-13 produced the most active catalysts with the smallest pores $(\sim 4$ $\AA$, 8-membered ring) and ZSM-5 showed medium activity with medium-size pore openings ( $5.5 \AA$, 10-membered ring). Meanwhile, beta zeolite had the lowest activity and $\mathrm{N}_{2}$ selectivity with the largest pores $(\sim 7 \AA$ and $\sim 5.5 \AA$, 12-membered ring). For these catalysts, the smaller pore sizes seemed to favor the desirable reaction pathways. However, detailed mechanistic studies and experimental results are needed to verify the correlation between pore size and activity/selectivity. In summary, both the activity and selectivity of $\mathrm{Cu}$-SSZ-13 for $\mathrm{NO}_{x}$-SCR using $\mathrm{NH}_{3}$ are superior to those of Cu-ZSM-5 and Cu-beta over the entire temperature range studied (up to $550{ }^{\circ} \mathrm{C}$ ). The catalytic activity can be further improved by preparing composite catalysts. The addition of cerium [76] and zirconia [87] increased the copper dispersion and prevented its crystallization, which improved the redox properties of the CuCe/ZSM-5 catalysts. As shown in Fig. 5(a), the light-off temperature (10\% NO conversion) was about $103{ }^{\circ} \mathrm{C}$ for $\mathrm{Cu} / \mathrm{ZSM}-5$ (Cu-Z), while the value shifted to $60{ }^{\circ} \mathrm{C}$ when the cerium content was increased in $2 \% \mathrm{Cu}+2 \% \mathrm{Ce}$ sample (CuCe4-Z). An NO conversion of $95 \%$ was reached at around $197{ }^{\circ} \mathrm{C}$ for $\mathrm{Cu}-\mathrm{Z}$, while the corresponding temperature was decreased to $148{ }^{\circ} \mathrm{C}$ for CuCe4-Z. According to Fig. 5(b), Cu-Zr exhibited excellent activity in SCR, with NO conversions above 95\% in the temperature range 197-404 ${ }^{\circ} \mathrm{C}$. When appropriate amounts of zirconium were added to $\mathrm{Cu} / \mathrm{ZSM}-5$, the temperature range for efficient NO reduction $(>95 \%)$ was extended to both lower and higher temperatures.

$\mathrm{Cu}-\mathrm{SSZ}-13$ powder catalysts with various ion-exchange lev- els were characterized to illustrate the relationship between catalytic performance and structure. As shown in Fig. 6(a), at low ion-exchange (IE) levels (such as IE $=23 \%$ ), there was only one $\mathrm{Cu}^{2+}$ ion within each hexagonal unit cell. In this case, hydrated $\mathrm{Cu}^{2+}$ ions were octahedrally coordinated at subambient temperatures, suggesting they were still coordinated to lattice oxygen atoms of the 6-membered rings [88]. As the $\mathrm{Cu}$ loading increased, it was possible that two $\mathrm{Cu}^{2+}$ ions could sit in one unit cell [89]. Some $\mathrm{Cu}^{2+}$ ions were located in the large CHA cages and close to 8-membered rings (Fig. 6(b)). Standard $\mathrm{NH}_{3}$-SCR reaction kinetics were measured at high-space velocities, which demonstrated that the reaction kinetics were controlled by intraparticle diffusion limitations [90]. These results suggested that, for the CHA SCR system, both washcoat and pore diffusion limitations should be considered for optimum practical application. The reaction rates increased with increasing $\mathrm{Cu}$ loadings due to weaker interactions between the $\mathrm{Cu}$ ions and zeolite framework at higher $\mathrm{Cu}$ loadings, which allowed more facile $\mathrm{Cu}^{2+} \leftrightarrow \mathrm{Cu}^{+}$redox cycling. Recent research showed that $\mathrm{NH}_{3}$-solvated $\mathrm{Cu}^{\mathrm{I}}$ ions have sufficient mobility to travel through 8-membered ring zeolite windows and form transient ion pairs that participate in an $\mathrm{O}_{2}$-mediated $\mathrm{Cu}^{\mathrm{I}} \rightarrow \mathrm{Cu}^{\mathrm{II}}$ redox [91]. As shown in Fig. 6(c), $\mathrm{N}_{2}, \mathrm{H}_{2} \mathrm{O}$, and $\mathrm{Cu}^{\mathrm{I}}\left(\mathrm{NH}_{3}\right)_{2}$ were produced by the reduction of $\mathrm{NO}$ and $\mathrm{NH}_{3}$ by $\mathrm{NH}_{3}$-solvated $\mathrm{Cu}^{\mathrm{II}}$ ions charge-compensating for either one (left cycle) or two (right cycle) framework Al sites. Mobile $\mathrm{Cu}^{\mathrm{I}}\left(\mathrm{NH}_{3}\right)_{2}$ species can diffuse and be oxidized by $\mathrm{O}_{2}$ to generate the $\mathrm{Cu}^{\mathrm{II}}$ dimer intermediate.

In addition to zeolite, many metal oxides are commonly used as catalyst supports for copper oxide [92]. $\mathrm{Al}_{2} \mathrm{O}_{3}$-based supports are the most studied materials in the $\mathrm{NH}_{3}-\mathrm{SCR}$ reaction [9]. Pure $\mathrm{Al}_{2} \mathrm{O}_{3}$ has no activity in the $\mathrm{NH}_{3}$-SCR reaction, mainly providing a high surface area to aid $\mathrm{CuO}_{x}$ dispersion on its surface and enhance catalytic performance.

$\mathrm{CuO}_{x}-\mathrm{X}$ represents a series of solid-solution composite copper oxides that have high activity for $\mathrm{NO}$, where $\mathrm{X}$ can be $\mathrm{CeO}_{2}$ and $\mathrm{Cu}-\mathrm{Mn}$ mixed oxides. Ce is the most used element for the modification of $\mathrm{CuO}_{x} \cdot \mathrm{CeO}_{2}$ is well known to have labile oxygen vacancies and bulk oxygen species with relatively high mobili-
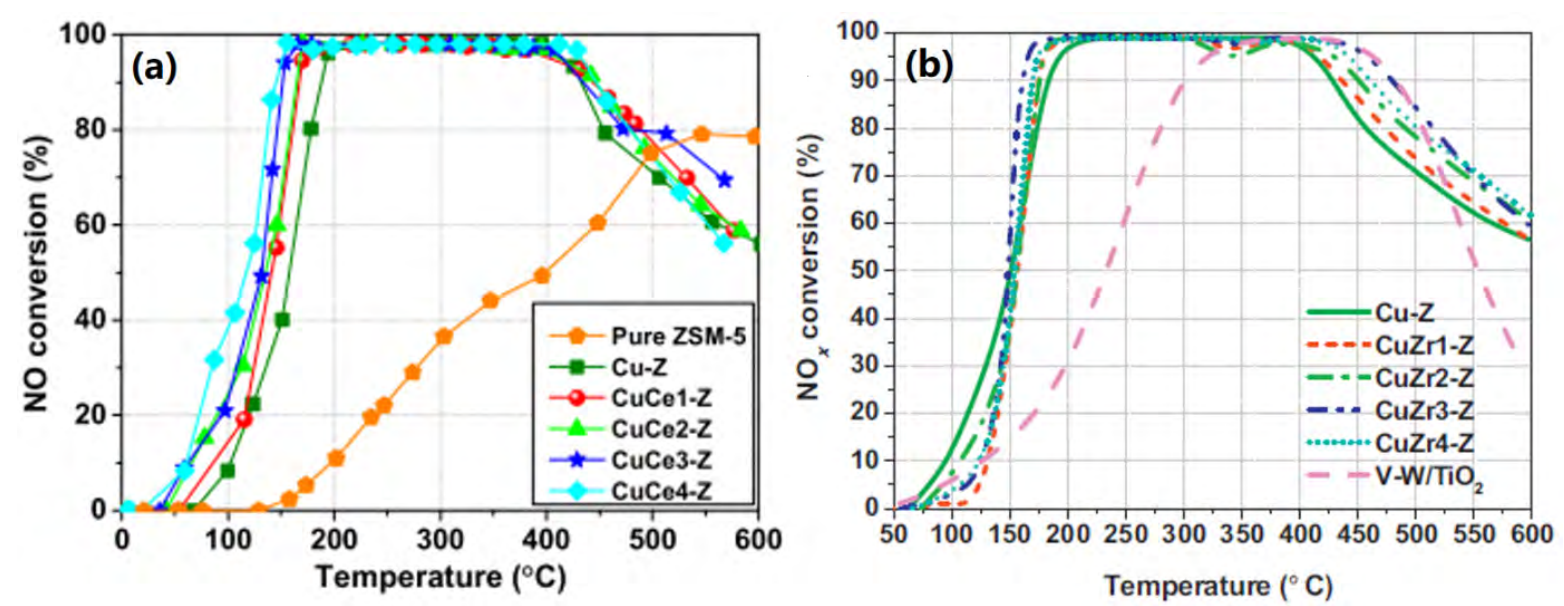

Fig. 5. (a) Catalytic activities for NO reduction using $\mathrm{NH}_{3}$ of pure ZSM-5, Cu-Z, CuCe1-Z, CuCe2-Z, CuCe3-Z, and CuCe4-Z catalysts, adapted from Ref. [76]; (b) SCR activity from $\mathrm{NO}_{x}$ conversions as a function of reaction temperature for $\mathrm{V}-\mathrm{W} / \mathrm{TiO}_{2}$, Cu-Z, and CuZr-Z catalysts, adapted from Ref. [87]. 

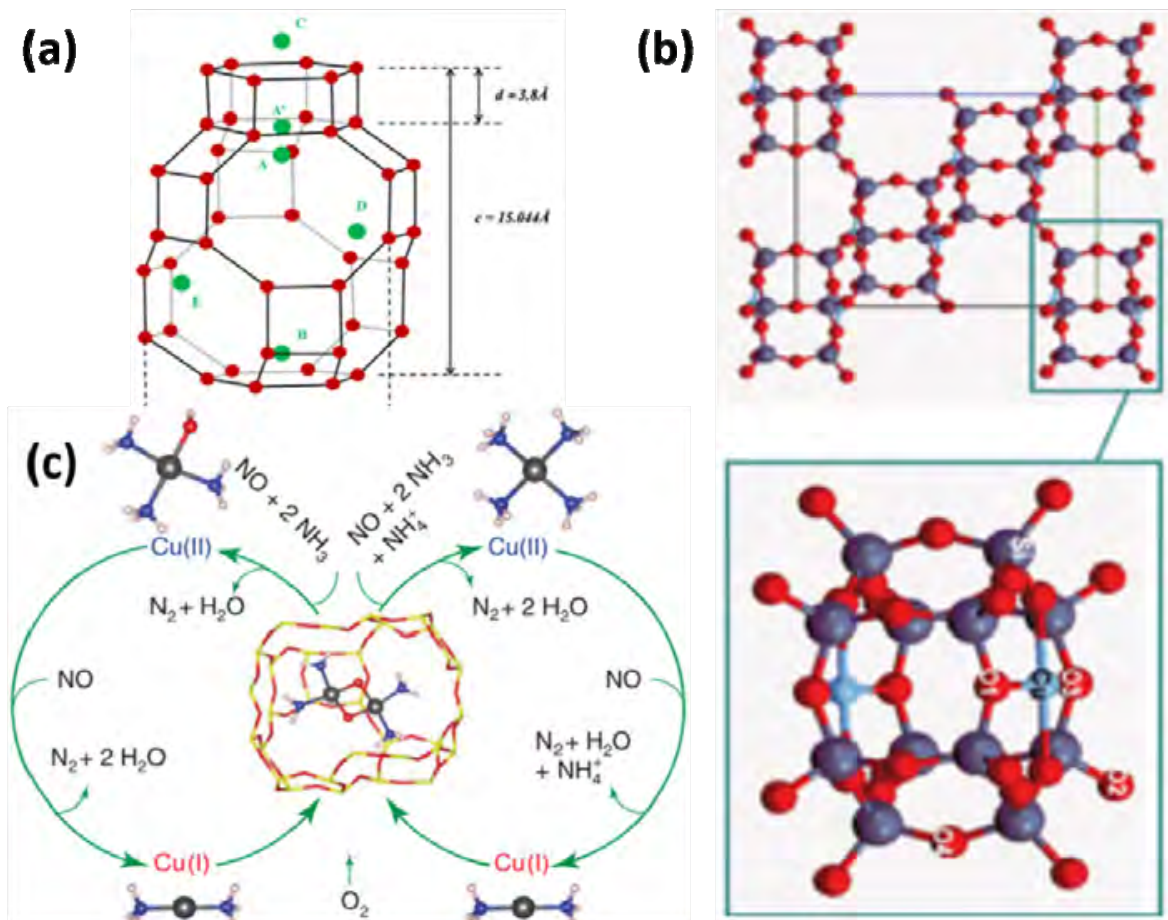

Fig. 6. (a) Schematic of the SSZ-13 hexagonal unit cell structure and possible $\mathrm{Cu}^{2+}$ locations, adapted from Ref. [73]; (b) Corresponding structure of Cu-SSZ-13 obtained from refinement and magnification of the d6r unit with Cu present as an isolated ion, adapted from Ref. [89]; (c) Proposed low-temperature SCR catalytic cycle, adapted from Ref. [91].

ty, and is easily formed during the redox shift between $\mathrm{Ce}^{4+}$ and $\mathrm{Ce}^{3+}$ under oxidizing and reducing conditions, respectively. Incorporation with $\mathrm{CuO}_{x}$ could enhance the performance of $\mathrm{CeO}_{2}$, for which the mechanism has been widely studied. The modulated distribution of $\mathrm{Cu}^{+}$achieved by adjusting the $\mathrm{Ce} / \mathrm{Cu}$ molar ratio was found to be crucial for optimizing the redox ability and acid properties. Outstanding $\mathrm{SO}_{2}$-resistant $\mathrm{NH}_{3}$-SCR performance (NO conversion close to $100 \%$ in the temperature range $250-350{ }^{\circ} \mathrm{C}$ under $200 \mathrm{ppm} \mathrm{SO}_{2}$ ) has been observed using $\left(\mathrm{CeO}_{x}\right)_{0.25} \mathrm{CuO}$ as catalyst [93].

\subsection{Catalytic activity of copper-based catalysts for VOC oxidation}

Volatile organic compounds (VOCs), emitted by various industrial processes and transportation activities, are considered important contributors to secondary particulate matter and atmospheric oxidants. Catalytic oxidation is among the most developed techniques for VOC elimination, as it requires lower energy consumption and emits less $\mathrm{NO}_{x}$ than thermal oxidation [94]. Metal oxides of $\mathrm{Cu}$ [95], $\mathrm{Cr}$ [96], and Co [97] are low cost alternatives to noble metals as catalysts for VOC oxidation with competitive performance.

Copper oxides are known to exhibit high catalytic activity in the oxidation of hydrocarbons. The morphology and shape of $\mathrm{Cu}_{2} \mathrm{O}$ had been shown to greatly influence the $\mathrm{CH}_{x}$ oxidation activity. Huang et al. [98] investigated the crystal-plane-controlled catalytic performance uniform capping-ligand-free $\mathrm{Cu}_{2} \mathrm{O}$ octahedra, cubes, and rhombic dodecahedra in propylene oxidation with $\mathrm{O}_{2}$. As shown in Fig. 7, the results indicated that
$\mathrm{Cu}_{2} \mathrm{O}$ cubes with exposed (100) crystal planes were the most selective for $\mathrm{CO}_{2}$.

Mixed metal oxides have been widely applied in the catalytic combustion of VOCs. Copper and yttrium-doped zirconia have been prepared and tested for the combustion of propene and toluene [99]. The results indicated that total combustion of propene and toluene was achieved at $350{ }^{\circ} \mathrm{C}$. This support should favor the formation of $\mathrm{CuO}$ particles that should be the active catalytic sites. $0.5 \% \mathrm{Pd}-\mathrm{NaFAU}$ zeolite and $5 \% \mathrm{Cu}-\mathrm{ZrO}_{2}$ were found to be promising catalysts for complete toluene oxidation. The activity of copper oxide was somewhat correlated to the oxygen mobility of the support, leading to easily reducible small copper species.

$\mathrm{CuO}-\mathrm{CeO}_{2}$ has been shown to be a powerful catalyst for oxidation reactions that is even comparable to supported noble metal catalysts due to the introduction of ceria, which stabilizes the active $\mathrm{Cu}$ sites, affecting $\mathrm{Cu}$ redox [61]. Plenty of $\mathrm{Cu}^{2+}$ ions in mesoporous $\mathrm{CuCeO}_{x}$ oxides were shown to be incorporated into the $\mathrm{CeO}_{2}$ lattice in the form of a $\mathrm{Cu}_{x} \mathrm{Ce}_{1-x} \mathrm{O}_{2-\sigma}$ solid solution, which produced large amounts of oxygen vacancies at $\mathrm{CuO}_{x}$ and $\mathrm{CeO}_{2}$ interfaces. Meanwhile, the $\mathrm{Cu}^{2+}-\mathrm{O}^{2-}-\mathrm{Ce}^{4+}$ connection in the solid solution can act as a bridge for oxygen transfer between $\mathrm{Cu}$ and $\mathrm{Ce}$, and enhance the reducibility of both components [100]. $\mathrm{Hu}$ et al. [101] have reported the high activity of a $\mathrm{CuO}-\mathrm{CeO}_{2}(10 \mathrm{at} \% \mathrm{Cu})$ catalyst in benzene oxidation. A higher calcination temperature would lead to more $\mathrm{Cu}^{2+}$ species and richer lattice oxygen species on the surface of the catalysts, which are favorable for benzene oxidation.

$\mathrm{Al}_{2} \mathrm{O}_{3}$-supported $\mathrm{CuO}_{x}$ has been prepared and tested in the combustion of VOCs, including methanol, ethanol, acetalde- 

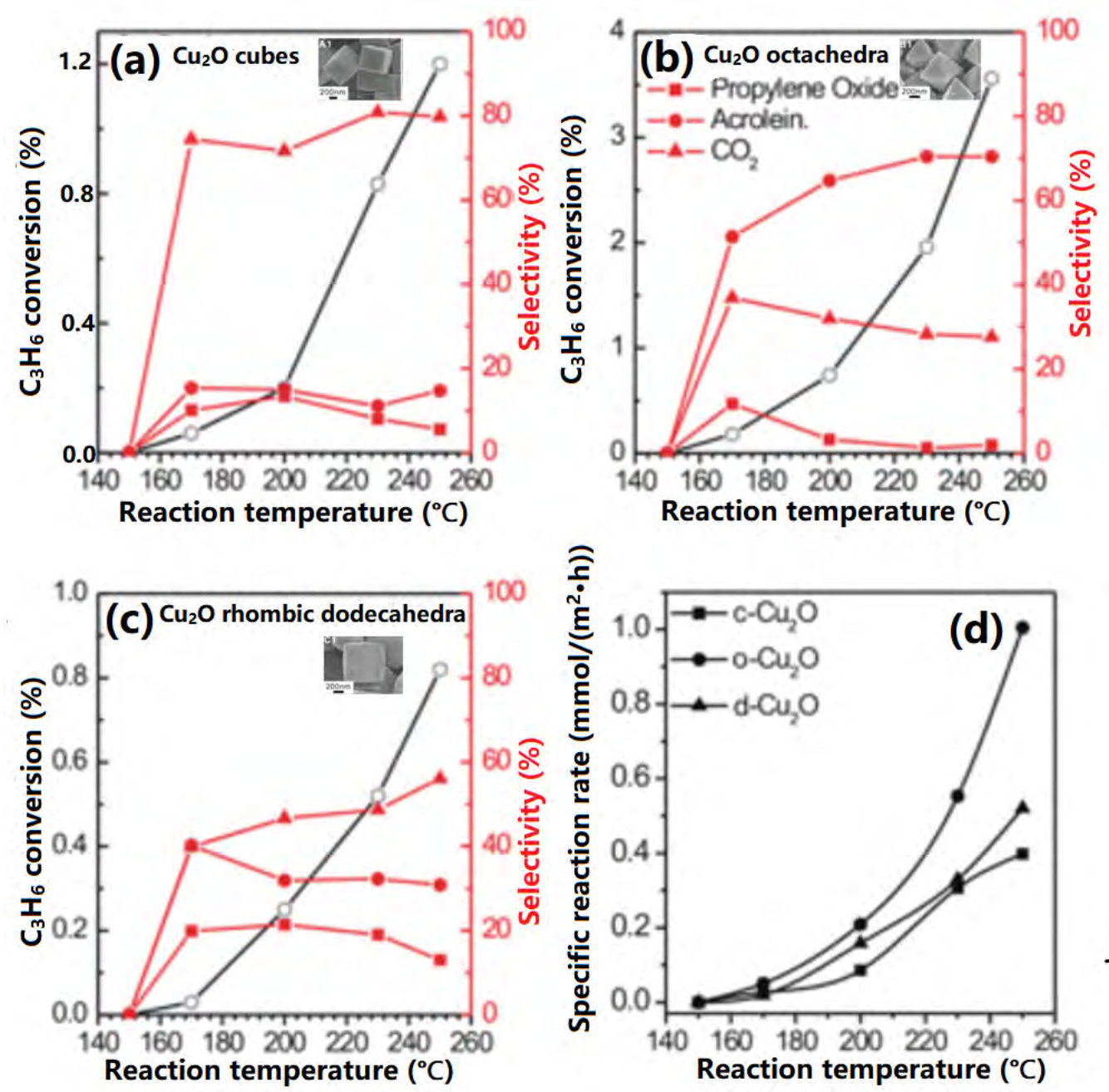

Fig. 7. Conversion and selectivity for propylene oxide, acrolein, and $\mathrm{CO}_{2}$ in $\mathrm{C}_{3} \mathrm{H}_{6}$ oxidation with $\mathrm{O}_{2}$ as catalyzed capping-ligand-free catalysts. (a) $\mathrm{Cu}_{2} \mathrm{O}$ cubes, (b) octahedra, and (c) rhombic dodecahedra. (d) Specific reaction rate of $\mathrm{C}_{3} \mathrm{H}_{6}$ oxidation with molecular oxygen catalyzed by capping-ligand-free $\mathrm{Cu}_{2} \mathrm{O}$ cubes $\left(\mathrm{c}-\mathrm{Cu}_{2} \mathrm{O}\right)$, octahedra $\left(\mathrm{o}-\mathrm{Cu}_{2} \mathrm{O}\right)$, and rhombic dodecahedra (d-Cu $\left.\mathrm{Cu}_{2} \mathrm{O}\right)$. Adapted from Ref. [98].

hyde, formic acid, and acetic acid [102]. The VOCs were typically adsorbed on the alumina surface, diffused, and then reacted on the $\mathrm{CuO}$ surface. Lattice oxygen in $\mathrm{CuO}$ is active for deep oxidation and, as lattice oxygen is depleted, the diffusion of lattice oxygen to the surface limits the oxidation rate. Supported $\mathrm{CuO}$ oxidizes VOCs with the order of reactivity as follows: $\mathrm{HCOOH}>\mathrm{CH}_{3} \mathrm{OH}>\mathrm{CH}_{3} \mathrm{COOH}>\mathrm{C}_{2} \mathrm{H}_{5} \mathrm{OH}>\mathrm{C}_{2} \mathrm{H}_{4} \mathrm{O}$. Águila et al. [35] prepared a series of $\mathrm{ZrO}_{2}, \mathrm{Al}_{2} \mathrm{O}_{3}$, and $\mathrm{SiO}_{2}$-supported copper oxide catalysts for the complete oxidation of methane. Among these, the better catalytic performance of $\mathrm{ZrO}_{2}$-supported copper oxide was related to the capacity of zirconia to stabilize highly dispersed $\mathrm{Cu}$ species. Activated carbon (AC)supported $\mathrm{CuO}$ catalysts were prepared using an incipientwetness impregnation method, resulting in a benzene removal efficiency of more than $80 \%$ when the inlet concentration ranged from 78 to $409 \mathrm{ppm}$. The high surface area (483.8 $\left.\mathrm{m}^{2} / \mathrm{g}\right)$ and well-developed porosity $(0.37 \mathrm{~mL} / \mathrm{g})$ of these catalysts governed their catalytic activity in benzene oxidation [33].

$\mathrm{CuO}-\mathrm{CeO}_{2}$ materials are effective oxidation catalysts due to the promoting effect of ceria, which possesses a high oxygen storage capacity and a facile $\mathrm{Ce}^{4+} / \mathrm{Ce}^{3+}$ redox cycle. Larsson et al. [94] have studied the oxidation of ethanol and ethyl acetate over $\mathrm{CuO} / \mathrm{TiO}_{2}$ and $\mathrm{CuO}-\mathrm{CeO}_{2} / \mathrm{TiO}_{2}$ catalysts. The interaction between cerium and copper results in improved reducibility of the active copper oxide species, which explains the improved catalytic activity. The facile $\mathrm{Ce}^{4+} / \mathrm{Ce}^{3+}$ cycle promoted copper reduction to generate predominantly $\mathrm{Cu}^{2+}$ species. Several $\mathrm{CuO}-\mathrm{CeO}_{2}$ catalysts have been prepared via the combustion method and their catalytic performance examined in the oxidation of ethanol, ethyl acetate, and toluene [104]. $\mathrm{Cu}-\mathrm{MnO}_{x}$ mixed oxides were also synthesized for the catalytic combustion of propane and ethanol [105]. The mixed oxides were prepared through coprecipitation at aging time of 4, 18 and 24 h. The catalytic activities of the $\mathrm{Cu}-\mathrm{Mn}$ mixed oxides in the total oxidation of propane indicated that the catalytic performance of $\mathrm{Cu}-\mathrm{MnO}_{x}$ binary metal oxides was better than that of pure $\mathrm{Mn}_{2} \mathrm{O}_{3}$ and $\mathrm{CuO}$ oxides. Furthermore, an increase in aging time could enhance the activity and selectivity for $\mathrm{CO}_{2}$ [106]. A $\mathrm{Cu}-\mathrm{Mn}$-Ce ternary mixed oxide catalyst has been prepared using a citric acid sol-gel method [103]. As shown in Fig. 8(a), this 
catalyst had a $\mathrm{Cu}-\mathrm{Mn}$-Ce molar ratio $=1: 2: 4$ and produced the highest catalytic activity, with $99 \%$ toluene conversion achieved at temperatures below $220^{\circ} \mathrm{C}$. Fig. 8(b) shows that the coexistence of $\mathrm{Cu}-\mathrm{Mn}$ mixed oxides and the ceria-based solid solution resulted in a strong synergetic interaction that promoted catalyst reducibility, increased oxygen mobility, and enhanced the formation of abundant active oxygen species. Surface and lattice oxygen in the $\mathrm{CeO}_{2}$-based solid solution were transported as active oxygen. Furthermore, organic molecules (benzene) were adsorbed and activated by highly dispersed surface $\mathrm{Cu}-\mathrm{Mn}$ mixed oxides, which acted as catalyst oxidation centers. The resulting structure was highly active for the catalytic combustion of VOCs $[107,108]$.

\section{Copper-based catalysts for the degradation of organic pollutants in wastewater}

Wastewater from industrial processes contains organic pollutants that can not only damage the aquatic environment, but also impact the entire ecosystem. These organic pollutants can be classified as organic pesticides, polycyclic aromatic hydrocarbon petroleum pollutants, and organic matter. Most of these compounds are carcinogenic and have been listed as toxic priority pollutants by the European Union and USA. Among various water remediation technologies, advanced oxidation processes (AOPs), which are based on the generation of reactive oxygen species (ROS), are regarded as effective technologies for the degradation of hazardous organic pollutants in wastewater. Compared with homogeneous catalysts, highly efficient heterogeneous catalysts have received more attention due to their easy separation and recycling from the liquid reaction system. The degradation of persistent organic pollutants using heterogeneous Fenton-like processes has received significant attention. The Fenton process is an AOP that uses ferrous ions and hydrogen peroxide to generate the second most powerful oxidant, hydroxyl radicals, in aqueous solution. Copper has multiple redox states and the ability to decompose $\mathrm{H}_{2} \mathrm{O}_{2}$ into $\mathrm{HO}^{-}$via conventional Fenton-like pathways [109]. Therefore, a catalyst containing copper can undergo a heterogeneous Fenton-like process in the presence of hydrogen peroxide and organic pollutants.

Angi et al. [110] synthesized copper oxide nanoparticles by sonicating copper acetate monohydrate with hydrogen peroxide. The heterogeneous Fenton activity of the prepared material for the degradation of methylene blue was also tested. The rate of dye removal was very high, perhaps due to the synergistic effect between $\mathrm{CuO}$ and $\mathrm{H}_{2} \mathrm{O}_{2}$ molecules, which facilitates fast decomposition of $\mathrm{H}_{2} \mathrm{O}_{2}$ to $\mathrm{HO} \cdot$ radicals [111].

Copper loaded on various supports has also shown high Fenton-like catalytic activity. Supported copper oxides were synthesized to enhance the dispersion of $\mathrm{Cu}$ active sites. Zhang et al. [112] fabricated a porous $\mathrm{CuO}-\gamma-\mathrm{Al}_{2} \mathrm{O}_{3}$ heterogeneous catalyst that offered superior activation efficiencies and good operational stability. Porous $\gamma-\mathrm{Al}_{2} \mathrm{O}_{3}$ played an important role in the dispersion of $\mathrm{CuO}$ particles, minimization of copper ions leaching into the liquid phase, and generation of $\mathrm{Cu}-\mathrm{OH}$ complexes on the surface, which is the critical step for heterogeneous activation of $\mathrm{H}_{2} \mathrm{O}_{2}$ via the certain amount of basic surface sites on $\gamma-\mathrm{Al}_{2} \mathrm{O}_{3}$. Zeolite is a promising catalyst support with microporous-mesoporous characteristics and specific surface properties. Ghosh et al. [113] loaded $\mathrm{Cu}$ nanoparticles onto SBA-15 for the removal of various dyes, such as 4-nitrophenol, methyl orange, congo red, rhodamine $B$, methylene blue, and mixtures of dyes, in the presence of excess $\mathrm{NaBH}_{4}$. This material exhibited high catalytic activity in the degradation of both single and mixed dyes, with dyes were removed within $8 \mathrm{~min}$ with high first-order reaction rate constants. Pradhan et al. [114] synthesized a mesoporous $\mathrm{Cu} / \mathrm{Al}_{2} \mathrm{O}_{3}-\mathrm{MCM}-41$ nanocomposite and applied it as a heterogeneous photo Fenton-like catalyst for the degradation of phenol, 2-chloro-4-nitrophenol and 4-chloro-2-nitrophenol in aqueous solution. Under low $\mathrm{pH}$ conditions ( $\mathrm{pH}=4$ ), nearly $100 \%$ degradation of all phenolic compounds was achieved within $45 \mathrm{~min}$. This catalyst was very efficient in the presence of sunlight, mainly due to its small particle size, easy copper reducibility, $\mathrm{Cu}^{2+}$ stabilization on the mesoporous $\mathrm{Al}_{2} \mathrm{O}_{3}-\mathrm{MCM}-41$ support, good textural properties, and higher activity under visible light. Ordered mesoporous carbon is another interesting support due to its large specific surface area, uniform pore size, and accessible mesopores [115]. A catalyst of iron-copper bimetallic nanoparticles em-
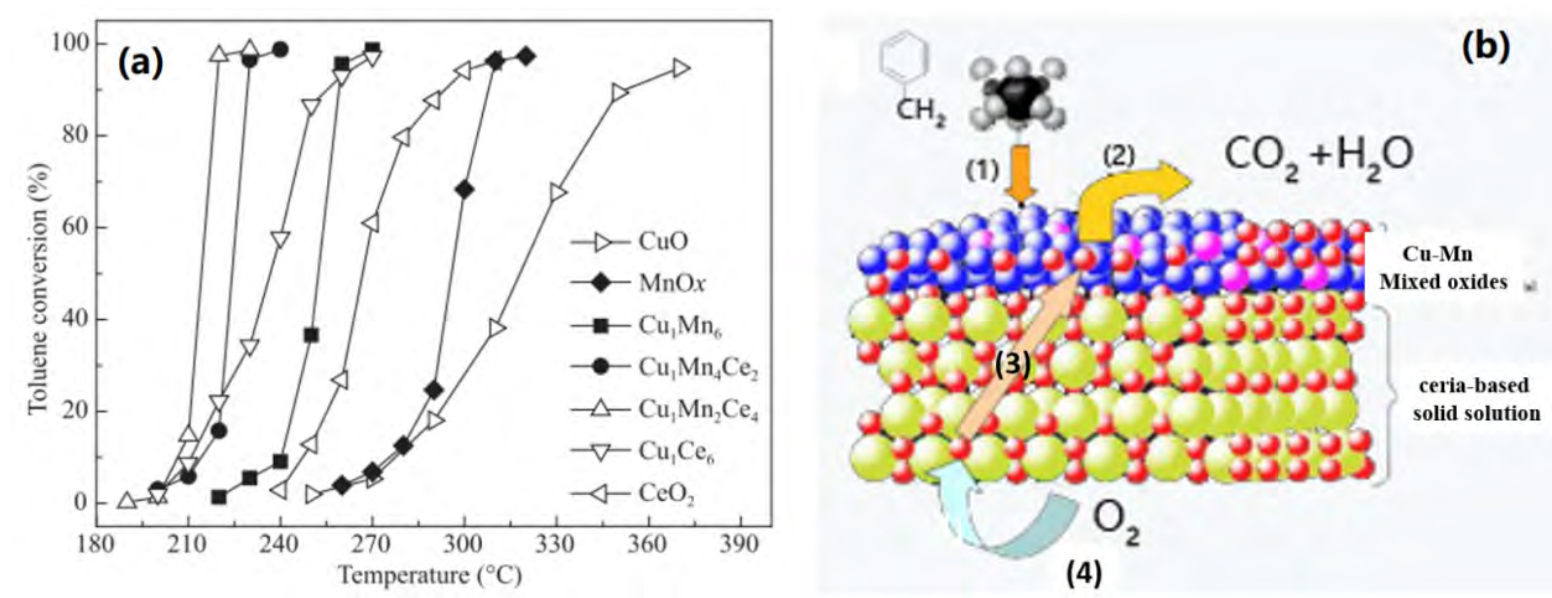

Fig. 8. (a) Light-off curves and (b) mechanism of toluene combustion over Cu-Mn-Ce mixed-oxide catalysts, adapted from Ref. [103]. 
bedded within an ordered mesoporous carbon composite (CuFe-MC) was synthesized via a self-assembly strategy as an effective and stable heterogeneous Fenton catalyst for the degradation of organic contaminants [116]. The high dispersion of iron-copper bimetallic nanoparticles in the ordered mesoporous carbon increased the amount of active sites. Furthermore, ordered mesoporous carbon used as a supporting material can also activate $\mathrm{H}_{2} \mathrm{O}_{2}$ to generate $\cdot \mathrm{OH}$ species, which are the active sites in the Fenton process.

Copper ferrite $\left(\mathrm{CuFe}_{2} \mathrm{O}_{4}\right)$, a magnetic spinel material with cubic structure, is a promising catalyst due to its medium saturation magnetization, excellent chemical stability, and mechanical strengths. The porous structure and high specific surface area of the catalyst afforded superior catalytic performance for the removal of imidacloprid [119]. Wang et al. [118] synthesized highly ordered mesoporous copper ferrite (meso- $\left.\mathrm{CuFe}_{2} \mathrm{O}_{4}\right)$, which possessed a high specific area $\left(122 \mathrm{~m}^{2} \mathrm{~g}^{-1}\right)$ and well-ordered mesoporous structure, as shown in Fig. 9(b) and (c), which contributed an enhanced number of active sites and benefitted the adsorption and mass transfer of large molecules. As shown in Fig. 9(e) and (f), the catalytic activity of catalysts with ordered mesoporous structures was superior to those of nonmesoporous structures (meso- $\mathrm{CuFe}_{2} \mathrm{O}_{4}>$ con- $\mathrm{CuFe}_{2} \mathrm{O}_{4}$, meso- $\mathrm{CoFe}_{2} \mathrm{O}_{4}>$ con- $\mathrm{CoFe}_{2} \mathrm{O}_{4}$ ), while $\mathrm{CuFe}_{2} \mathrm{O}_{4}$ was superior to $\mathrm{CoFe}_{2} \mathrm{O}_{4}$. The persulfate successfully degrade organic pollutants over a wide $\mathrm{pH}$ range due to its high standard oxidation potential ( $2.6 \mathrm{~V}$ ), which allowed easy activation to generate free sulfate radicals $\left(\mathrm{SO}_{4}{ }^{--}\right)$with a longer half-life. $\mathrm{Fe}^{3+}$ reduction by $\mathrm{Cu}^{+}$was thermodynamically favorable, which benefitted the $\mathrm{Fe}^{2+} / \mathrm{Fe}^{3+}$ and $\mathrm{Cu}^{+} / \mathrm{Cu}^{2+}$ redox cycles in meso- $\mathrm{CuFe}_{2} \mathrm{O}_{4}$ [120]. As shown in Fig. 9(a), a possible mechanism for persulfate activation by $\mathrm{CuO}-\mathrm{Fe}_{3} \mathrm{O}_{4}$ was proposed. First, a Fenton-like reaction occurs between $\mathrm{Cu}(\mathrm{II})$ and $\mathrm{S}_{2} \mathrm{O}_{8}{ }^{2-}$ at the surface of $\mathrm{CuO}-\mathrm{Fe}_{3} \mathrm{O}_{4}$, associated with the formation of $\mathrm{Cu}(\mathrm{III})$ and $\mathrm{SO}_{4}{ }^{--}$, which might lead to the formation of $\mathrm{HO} \cdot$ radicals [117]. The $\mathrm{CuO}-\mathrm{Fe}_{3} \mathrm{O}_{4}$ catalyst is relatively stable because it remained in the spinel crystalline form in the cubic phase at $\mathrm{pH}$ $=11.0$. However, the reason for the gradually declining catalytic activity observed at $\mathrm{pH}=11.0$ is unclear.

Kalal et al. [121] prepared a copper pyrovanadate photo Fenton catalyst using a wet chemical method and applied it to the degradation of neutral red and azure B. The authors found that the photo Fenton activity of copper pyrovanadate was much higher than those of $\mathrm{CuO}$ and $\mathrm{V}_{2} \mathrm{O}_{5}$. This enhanced efficiency was mainly due to the simultaneous activation of hydrogen peroxide in the presence of copper and vanadium.

\section{Copper-based catalysts for solid waste remediation}

Copper-based catalysts have also been intensively investigated in solid waste remediation and have shown promising performance. Soot particulates emitted from diesel engines have attracted much attention due to the serious damage they cause to the human body and environment [122]. Vehicle manufacturers have made good progress in eliminating soot from emissions. Currently, the combination of diesel particulate filters (DPFs) with soot oxidation catalysts is regarded as the most efficient after-treatment technology. Several copper ox-
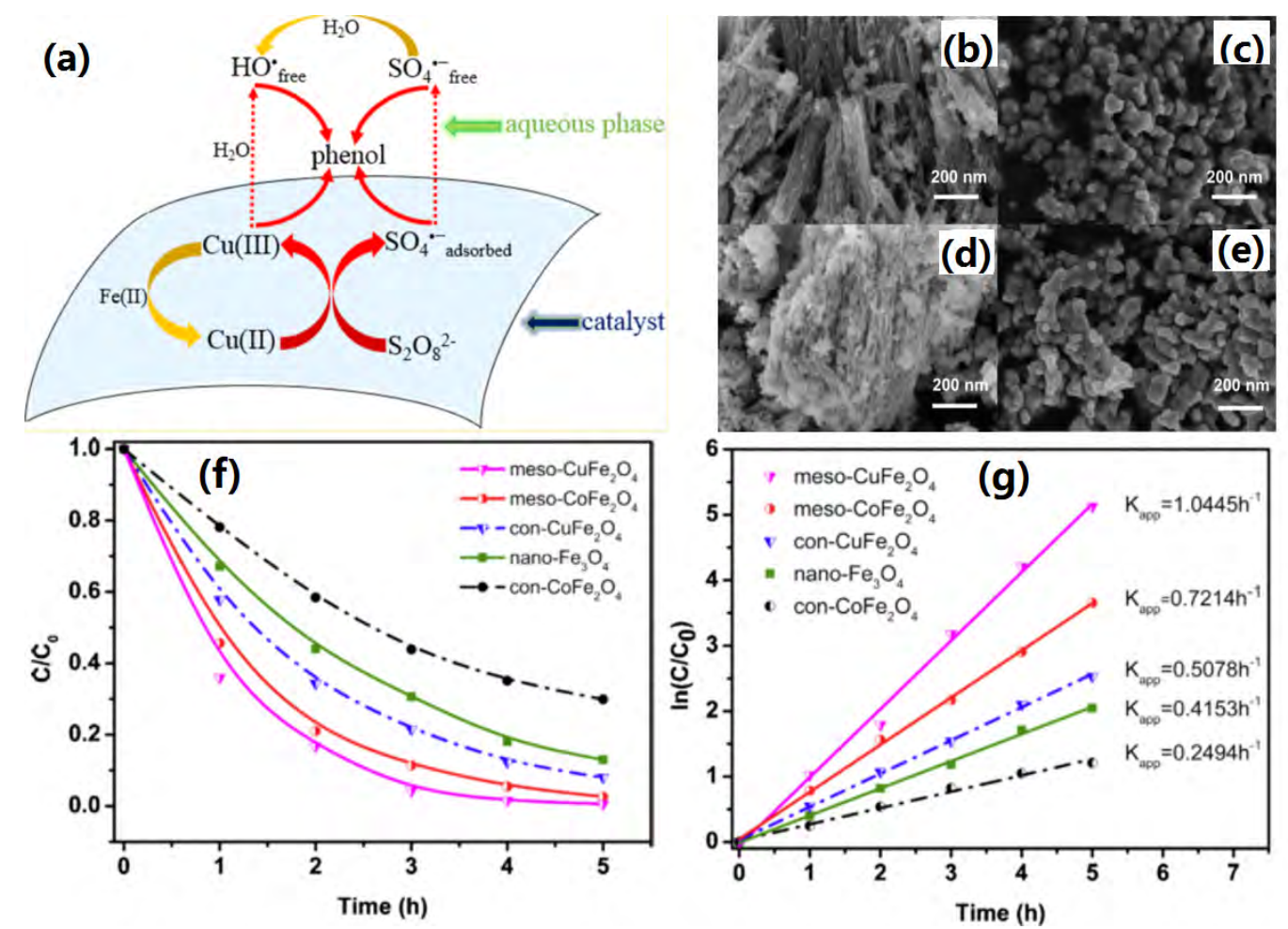

Fig. 9. (a) Mechanism of persulfate activation by $\mathrm{CuO}-\mathrm{Fe}_{3} \mathrm{O}_{4}$, adapted from Ref. [117]; $\mathrm{SEM}$ images of (b) meso-CuFe $\mathrm{O}_{4}$, (c) con-CuFe $\mathrm{O}_{4}$, (d) meso- $\mathrm{CoFe}_{2} \mathrm{O}_{4}$, and (e) con-CoFe $\mathrm{O}_{4}$; (f) Removal efficiency of imidacloprid using different catalysts; (g) Kinetic analysis of imidacloprid degradation $\left(\ln \left(\mathrm{C} / \mathrm{C}_{0}\right)\right.$ vs. time); Adapted from Ref. [118]. 
ides, such as mixed oxides or perovskite-like oxides, have been shown to be effective for soot catalytic combustion.

It is difficult for soot particles to enter the inner pores of most catalysts with meso- or microporous structures because they usually possess a large diameter of more than $25 \mathrm{~nm}$. Increasing the pore diameter to the macroscale can improve the soot combustion activity. Through the reasonable design of catalyst morphology, the catalytic activity for soot combustion can be efficiently improved. The morphological design of $\mathrm{CuO}$ arrays is important for the synthesis of highly efficient soot combustion catalysts to increase the contact efficiency between the catalysts and soot. Fig. 10(b) and (c) show good contact conditions between soot particles and $\mathrm{CuO}$ nanorods, similar to raindrops on a blade. The abundant space among loaded nanorods was also convenient for the transfer of reaction gases [123]. Lawn-like CuO-based nanorod array catalysts exhibited excellent performance for diesel soot combustion in gravitational contact mode (Fig. 10(d)) and the inverse structure catalyst, with $\mathrm{CeO}_{2}$ supported on the $\mathrm{CuO}$ surface, efficiently inhibited the sintering of $\mathrm{Cu}$ species and maintained the existence of active sites at the interface.

Ce-based or Ce-Zr mixed-oxide-supported $\mathrm{Cu}$ oxide have also been used for soot oxidation. Sudarsanam et al. [124] designed $\mathrm{CuO}_{x}$ nanoparticle-decorated $\mathrm{CeO}_{2}$ nanocubes with high catalytic performance in soot oxidation, as shown in Fig. 10(e) and (f). The presence of a higher number of $\mathrm{Ce}^{3+}$ ions and abundant oxygen vacancies at the $\mathrm{Cu}_{x}-\mathrm{CeO}_{2}$ nano-interface was responsible for the catalytic performance achieved by $\mathrm{CuO}_{x}-\mathrm{CeO}_{2}$ heterogeneous nanocatalysts $[125,126]$. To further enhance the performance of $\mathrm{Cu}-\mathrm{Mn}$-Ce mixed oxides, Liang et al. [127] reported the interaction between copper and cerium, which greatly enhanced the rapid release of lattice oxygen in a reducing atmosphere due to the incorporation of $\mathrm{Mn}^{\mathrm{x}+}$ into the CeO lattice.

Copper solid solution catalyst $\mathrm{CuO} / \mathrm{Ce}_{0.8} \mathrm{Zr}_{0.2} \mathrm{O}_{2}$ showed high catalytic activity due to its surface properties and the synergistic effect at the Cu-ceria interface $[128,129]$. The soot combustion rate at $400^{\circ} \mathrm{C}$ obtained using a copper/ceria-zirconia catalyst approached that of $1 \% \mathrm{Pt} / \mathrm{Al}_{2} \mathrm{O}_{3}$, making it a promising candidate for DPF catalysts with the benefit of lower cost compared with noble metals.

A Cu-based perovskite oxide catalyst has also been reported in soot oxidation. The porous structural characteristics of perovskite contribute to soot capture and catalytic performance in soot combustion, which is largely affected by the chemical composition, grain size, specific surface area, and pore structure [130]. Those structure features are directly related to the ion substitution ratio and calcination temperature [131]. Nanometric perovskite catalyst $\mathrm{La}_{1-x} \mathrm{~K}_{x} \mathrm{Co}_{1-y} \mathrm{CuO}_{3-\sigma}$ possesses high activity and a large amount of surface oxygen species $\left(\mathrm{O}^{2-}\right.$ and
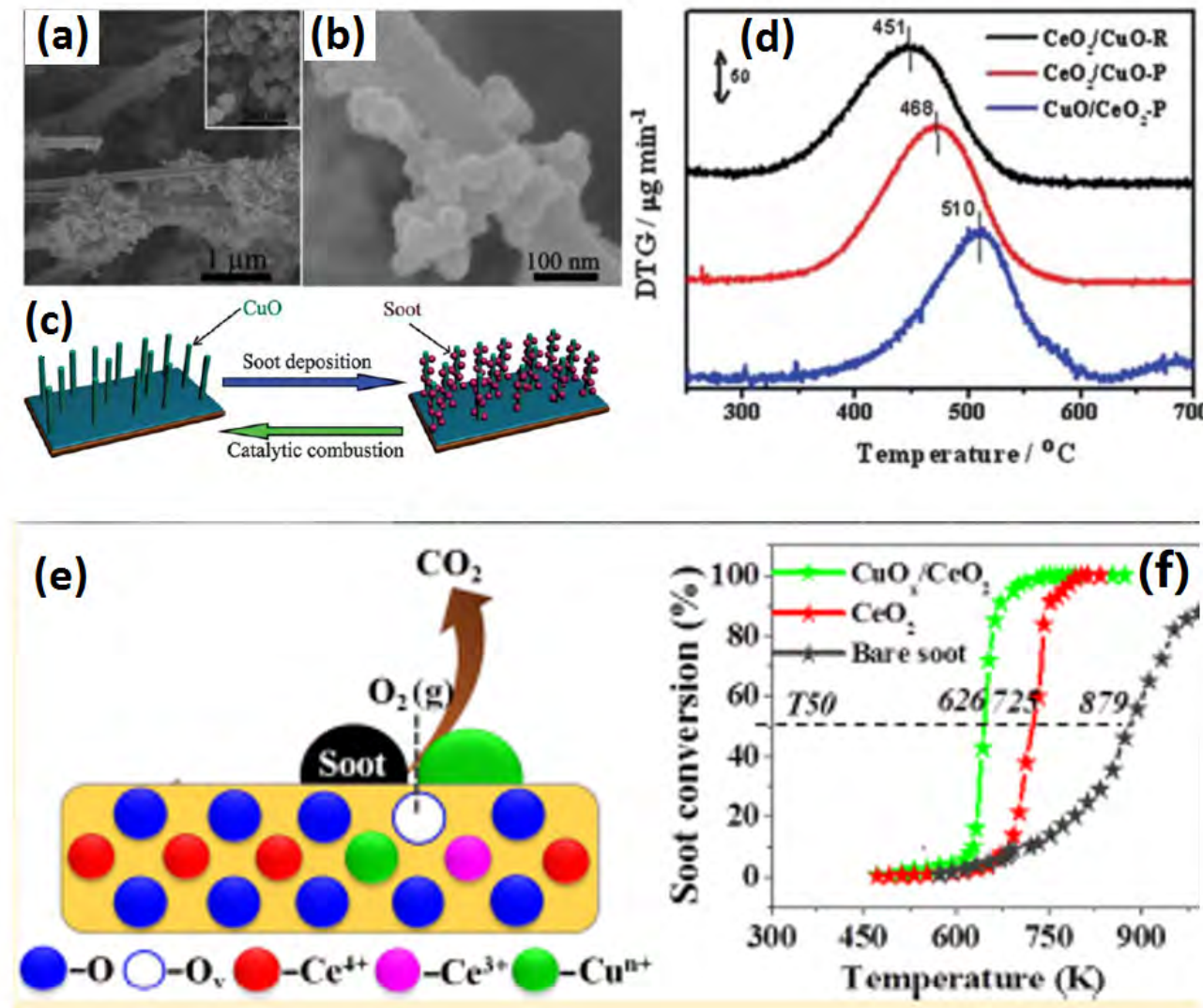

Fig. 10. (a, b) SEM images of the mixture of soot and nanorod array under gravitational contact mode (GCM); (c) Schematic illustration of the mechanism for lawn-like CuO-based nanorods array used for diesel soot combustion under GCM; (d) Derivative thermogravimetry (DTG) profiles of soot combustion, adapted from Ref. [123]; (e) Schematic diagram of the oxidation of diesel soot over $\mathrm{CuO}_{x}$-decorated CeO $\mathrm{O}_{2}$ nanocubes; (f) Soot conversion vs. temperature under tight contact conditions, adapted from Ref. [124]. 
$\mathrm{O}^{-}$), with more tetravalent cobalt ions and better reducibility than other catalysts, which resulted in its superior catalytic performance [132].

\section{Conclusions and prospect}

This review summarizes recent progress in copper-based non-precious metal heterogeneous catalysts for environmental remediation, focusing on the catalytic oxidation of carbon monoxide, the selective catalytic reduction (SCR) of $\mathrm{NO}_{x}$ using $\mathrm{NH}_{3}$, the catalytic oxidation of VOCs, the catalytic degradation of organic pollutants, and the catalytic oxidation of soot. Copper oxides exhibited various functions in these heterogeneous catalytic reactions. $\mathrm{CuO}_{x}$ can serve as a model catalyst to better elucidate the origin of catalytic active sites and the mechanism of different catalytic reactions. The structure-activity relationship of Cu-based catalysts has been touched on to illustrate the general principle for the rational design of highly efficient catalysts. Supported $\mathrm{CuO}_{x}$ can effectively enlarge the surface area necessary for high $\mathrm{CuO}_{x}$ dispersion and engineer interfacial catalytic active sites to further improve the physical and/or chemical properties of the corresponding composite catalysts. Solid solution $\mathrm{CuO}_{x}$-X composites are promising catalysts with unique atomic arrangements that can promote both the low-temperature activity and catalytic stability of $\mathrm{CuO}_{x}$ for applications under practical industrial conditions.

However, copper-based catalysts still suffer from many problems that inhibit their wide application that need to be addressed in future, as follows: (1) $\mathrm{CuO}_{x}$ nanoparticle aggregation: At higher $\mathrm{Cu}$ content in the catalyst, dispersed $\mathrm{CuO}$ small nanoparticles will aggregate to form large nanoparticles, accompanied by serious catalytic activity degradation; (2) Easily poisoned by $\mathrm{SO}_{2}$ and moisture: $\mathrm{SO}_{2}$ and moisture can poison $\mathrm{Cu}$-zeolites by forming $\mathrm{CuSO}_{3}$ at low temperatures $\left(<200{ }^{\circ} \mathrm{C}\right)$, which can block the zeolite pores and/or cover the active sites; (3) Poor low-temperature catalytic activity: The development of active and stable copper based catalysts for low-temperature pollutant control remains a significant challenge.

To address these issues, a few design principles might guide the rational fabrication of effective $\mathrm{Cu}$-based catalysts. The engineering of strong metal oxide-support interactions at the interface by controlling the morphology and facets could effectively prevent particle aggregation and the associated degradation of catalytic activity. To fabricate $\mathrm{CuO}_{x}$ catalysts with enhanced durability and strong resistance to $\mathrm{H}_{2} \mathrm{O}$ and $\mathrm{SO}_{2}$, the design of multiple active sites or trapping sites for $\mathrm{H}_{2} \mathrm{O}$ and $\mathrm{SO}_{2}$ could be emphasized. Engineering high index facets and high-energy interfacial structure that feature reversible oxidation capabilities could enhance the catalytic activity of $\mathrm{CuO}_{x}$ catalysts at low temperature. Furthermore, single-atom catalysts have shown excellent high specific activities with decreased metal particle sizes and maximized utilization of metallic materials. Therefore, a single-atom $\mathrm{Cu}$ catalyst would be an interesting and promising catalyst to explore. Although extensive effort has been devoted to address these problems, the limited progress should motivate increased attention toward tailoring these potential catalysts moving forward.

\section{Acknowledgments}

The authors are grateful for the financial support from the Recruitment Program of Global Young Experts start-up funds, the Program of Introducing Talents of Discipline to Universities of China (111 Program, B17019), and the National Natural Science Foundation of China (21777051).

\section{References}

[1] R. G. Rice, Ozone Sci. Eng., 1996, 18, 477-515.

[2] R. R. Bacsa, J. Kiwi, Appl. Catal. B, 1998, 16, 19-29.

[3] H. Xu, K. Ni, X. K. Li, S. Zhu, G. H. Fan, Chin. J. Catal., 2017, 38, 1261-1269.

[4] X. Xiang, P. Wu, Y. Cao, L. Cao, Q. Wang, S. Xu, P. Tian, Z. Liu, Chin. J. Catal., 2017, 38, 918-927.

[5] X. J. Yao, L. F. Chen, T. Kong, S. Ding, Q. Y. Luo, F. Yang, Chin. J. Catal., 2017, 38, 1423-1430.

[6] Y. X. Liu, J. G. Deng, S. H. Xie, Z. W. Wang, H. X. Dai, Chin. J. Catal., 2016, 37, 1193-1205.

[7] B. Zhu, X. S. Li, P. Sun, J. L. Liu, X. Y. Ma, X. Zhu, A. M. Zhu, Chin, J. Catal., 2017, 38, 1759-1769.

[8] X. Liu, Y. H. Zhang, Y. S. Jia, J. Z. Jiang, Y. B. Wang, X. S. Chen, T. Gui, Chin. J. Catal., 2017, 38, 1770-1779.

[9] B. F. Jin, Y. C. Wei, Z. Zhao, J. Liu, Y. Z. Li, R. J. Li, A. J. Duan, G. Y. Jiang, Chin. J. Catal., 2017, 38, 1629-1641.

[10] F. J. Maldonado-Hódar, C. Moreno-Castilla, A. F. Pérez-Cadenas, Appl. Catal. B, 2004, 54, 217-224.

[11] A. M. Carrillo, J. G. Carriazo, Appl. Catal. B, 2015, 164, 443-452.

[12] K. Everaert, J. Baeyens, J. Hazard. Mater., 2004, 109, 113-139.

[13] H. L. Tidahy, S. Siffert, F. Wyrwalski, J. F. Lamonier, A. Aboukaïs, Catal. Today, 2007, 119, 317-320.

[14] Y. B. Guo, Z. Ren, W. Xiao, C. H. Liu, H. Sharma, H. Y. Gao, A. Mhadeshwar, P. X. Gao, Nano Energy, 2013, 2, 873-881.

[15] Z. Ren, Z. L. Wu, W. Q. Song, W. Xiao, Y. B. Guo, J. Ding, S. L. Suib, P. X. Gao, Appl. Catal. B, 2016, 180, 150-160.

[16] Z. Ren, V. Botu, S. B. Wang, Y. T. Meng, W. Q. Song, Y. B. Guo, R. Ramprasad, S. L. Suib, P. X. Gao, Angew. Chem. Int. Ed., 2014, 53, 7223-7227.

[17] U. Deka, I. Lezcano-Gonzalez, B. M. Weckhuysen, A. M. Beale, ACS Catal., 2013, 3, 413-427.

[18] H. B. Liu, Z. Liu, X. M. Qian, Y. B. Guo, S. Cui, L. F. Sun, Y. L. Song, Y. L. Li, D. B. Zhu, Cryst. Growth Des., 2010, 10, 237-243.

[19] H. W. Huang, L. Q. Zhang, K. W. Wu, Q. Yu, R. Chen, H. S. Yang, X. S. Peng, Z. Z. Ye, Nanoscale, 2012, 4, 7832-7841.

[20] M. B. Gawande, A. Goswami, F. X. Felpin, T. Asefa, X. X. Huang, R. Silva, X. X. Zou, R. Zboril, R. S. Varma, Chem. Rev., 2016, 116, 3722-3811.

[21] W. M. Jin, J. H. Kang, J. H. Moon, ACS Appl. Mater. Interfaces, 2010, 2, 2982-2986.

[22] X. Wang, C. Liu, B. J. Zheng, Y. Q. Jiang, L. Zhang, Z. X. Xie, L. S. Zheng, J. Mater. Chem. A, 2013, 1, 282-287.

[23] H. Z. Bao, W. H. Zhang, D. L. Shang, Q. Hua, Y. S. Ma, Z. Q. Jiang, J. L. Yang, W. X. Huang, J. Phys. Chem. C, 2010, 114, 6676-6680.

[24] C. H. Kuo, C. H. Chen, M. H. Huang, Adv. Funct. Mater., 2007, 17, 3773-3780.

[25] C. H. Kuo, M. H. Huang, J. Phys. Chem. C, 2008, 112, 18355-18360.

[26] X. D. Liang, L. Gao, S. W. Yang, J. Sun, Adv. Mater., 2009, 21, 2068-2071.

[27] W. X. Huang, Top. Catal., 2013, 56, 1363-1376.

[28] X. Q. Wang, G. C. Xi, S. L. Xiong, Y. K. Liu, B. J. Xi, W. C. Yu, Y. T. Qian, 
Cryst. Growth Des., 2007, 7, 930-934.

[29] M. H. Cao, C. W. Hu, Y. Wang, Y. H. Guo, C. X. Guo, E. B. Wang, Chem. Commun., 2003, 1884-1885.

[30] H. W. Hou, Y. Xie, Q. Li, Cryst. Growth Des., 2005, 5, 201-205.

[31] G. F. Zou, H. Li, D. W. Zhang, K. Xiong, C. Dong, Y. T. Qian, J. Phys. Chem. B, 2006, 110, 1632-1637.

[32] S. Y. Yang, C. F. Wang, L. Chen, S. Chen, Mater. Chem. Phys., 2010, 120, 296-301.

[33] N. Xu, W. N. Fu, C. He, L. F. Cao, X. H. Liu, J. L. Zhao, H. Pan, Plasma Chem. Plasma Process., 2014, 34, 1387-1402.

[34] G. Oxide, Z. Xiong, L. L. Zhang, X. Song, Chem. Eng. J., 2011, 17, 2428-2434.

[35] G. Águila, F. Gracia, J. Cortés, P. Araya, Appl. Catal. B, 2008, 77, 325-338.

[36] J. H. Li, H. Z. Chang, L. Ma, J. M. Hao, R. T. Yang, Catal. Today, 2011, 175, 147-156.

[37] B. Skarman, D. Grandjean, R. E. Benfield, A. Hinz, A. Andersson, L. Reine Wallenberg, J. Catal., 2002, 211, 119-133.

[38] Q. F. Deng, T. Z. Ren, A. Bao, Y. P. Liu, Z. Y. Yuan, J. Ind. Eng. Chem., 2014, 20, 3303-3312.

[39] A. E. Baber, X. F. Yang, H. Y. Kim, K. Mudiyanselage, M. Soldemo, J. Weissenrieder, S. D. Senanayake, A. Al-Mahboob, J. T. Sadowski, J. Evans, J. A. Rodriguez, P. Lin, F. M. Hoffmann, J. G. Chen, D. J. Stacchiola, Angew. Chem. Int. Ed., 2014, 53, 5336-5340.

[40] E. Amini, M. Rezaei, Chin. J. Catal., 2015, 36, 1711-1718.

[41] E. Amini, M. Rezaei, M. Sadeghinia, Chin. J. Catal., 2013, 34, 1762-1767.

[42] M. J. Zhou, L. L. Cai, M. Bajdich, M. García-Melchor, H. Li, J. J. He, J. Wilcox, W. D. Wu, A. Vojvodic, X. L. Zheng, ACS Catal,, 2015, 5, $4485-4491$.

[43] Z. P. Qu, Z. Wang, X. Y. Zhang, H. Wang, Catal. Sci. Technol., 2016, 6, 4491-4502.

[44] Y. R. Li, H. G. Peng, X. L. Xu, Y. Peng, X. Wang, RSC Adv. 2015, 5, 25755-25764.

[45] A. J. Binder, T. J. Toops, R. R. Unocic, J. E. Parks II, S. Dai, Angew. Chem. Int. Ed., 2015, 54, 13263-13267.

[46] Z. G. Xie, X. X. Zhou, H. X. Wu, L. S. Chen, H. Zhao, Y. Liu, L. Y. Pan, H. R. Chen, Sci. Reports, 2016, 6, 30132.

[47] Y. X. Shen, Y. Guo, L. Wang, Y. Q. Wang, Y. L. Guo, X. Q. Gong, G. Z. Lu, Catal. Sci. Technol., 2011, 1, 1202-1207.

[48] R. Prasad, P. Singh, Catal. Rev. Sci. Eng., 2012, 54, 224-279.

[49] T. J. Huang, D. H. Tsai, Catal. Lett., 2003, 87, 173-178.

[50] U. R. Pillai, S. Deevi, Appl. Catal. B, 2006, 64, 146-151.
[51] D. Zhao, C. M. Tu, X. J. Hu, N. Zhang, RSC $A d v$, 2017, 7, 37596-37603.

[52] K. B. Zhou, R. P. Wang, B. Q. Xu, Y. D. Li, Nanotechnology, 2006, 17, 3939-3943.

[53] Y. F. Guo, J. Lin, C. H. Li, S. X. Lu, C. W. Zhao, Catal. Lett., 2016, 146, 2364-2375.

[54] W. Liu, A. F.Sarofim. M. Flytzani-Stephanopoulos, Chem. Eng. Sci., 1995, 49, 4871-4888.

[55] A. Martínez-Arias, M. Fernández-García, O. Gálvez, J. M. Coronado, J. A. Anderson, J. C. Conesa, J. Soria, G. Munuera, J. Catal., 2000, $195,207-216$.

[56] A. P. Jia, S. Y. Jiang, J. Q. Lu, M. F. Luo, J. Phys. Chem. C, 2010, 114, 21605-21610.

[57] J. S. Elias, N. Artrith, M. Bugnet, L. Giordano, G. A. Botton, A. M. Kolpak, Y. Shao-Horn, ACS Catal, 2016, 6, 1675-1679.

[58] S. Y. Yao, K. Mudiyanselage, W. Q. Xu, A. C. Johnston-Peck, J. C. Hanson, T. P. Wu, D. Stacchiola, J. A. Rodriguez, H. Y. Zhao, K. A. Beyer, K. W. Chapman, P. J. Chupas, A. Martínez-Arias, R. Si, T. B. Bolin, W. J. Liu, S. D. Senanayake, ACS Catal., 2014, 4, 1650-1661.

[59] G. Sedmak, S. Hočevar, J. Levec, J. Catal,, 2003, 213, 135-150.

[60] M. F. Luo, Y. P. Song, J. Q. Lu, X. Y. Wang, Z. Y. Pu, J. Phys. Chem. C, 2007, 111, 12686-12692.

[61] M. F. Luo, J. M. Ma, J. Q. Lu, Y. P. Song, Y. J. Wang, J. Catal., 2007, $246,52-59$.

[62] D. Gamarra, G. Munuera, A. B. Hungría, M. Fernández-García, J. C. Conesa, P. A. Midgley, X. Q. Wang, J. C. Hanson, J. A. Rodríguez, A. Martínez-Arias, J. Phys. Chem. C, 2007, 111, 11026-11038.

[63] C. D. Curran, L. Lu, C. J. Kiely, S. McIntosh, J. Mater. Chem. A, 2018, 6, 244-255.

[64] X. Zhou, J. Ling, W. L. Sun, Z. Q. Shen, J. Mater. Chem. A, 2017, 5, 9717-9722.

[65] L. Zhou, X. X. Li, Z. Yao, Z. W. Chen, M. Hong, R. S. Zhu, Y. Y. Liang, J. Zhao, Sci. Reports, 2016, 6, 23900.

[66] B. Eren, C. Heine, H. Bluhm, G. A. Somorjai, M. Salmeron, J. Am. Chem. Soc., 2015, 137, 11186-11190.

[67] A. E. Baber, X. Yang, H. Y. Kim, K. Mudiyanselage, M. Soldemo, J. Weissenrieder, S. D. Senanayake, A. Al-Mahboob, J. T. Sadowski, J. Evans, J. A. Rodriguez, P. Liu, F. M. Hoffmann, J. G. Chen, D. J. Stacchiola, Angew. Chem. Int. Ed., 2014, 53, 5336-5340.

[68] H. Y. Kim, P. Liu, J. Phys. Chem. C, 2015, 119, 22985-22991.

[69] Z. R. Tang, C. D. Jones, J. K.W. Aldridge, T. E. Davies, J. K. Bartley, A. F. Carley, S. H. Taylor, M. Allix, C. Dickinson, M. J. Rosseinsky, J. B. Claridge, Z. Xu, M. J. Crudace, G. J. Hutchings, Chem. Catal. Chem.,

\section{Graphical Abstract}

Chin. J. Catal., 2018, 39: 566-582 doi: 10.1016/S1872-2067(17)62996-6

Copper-based non-precious metal heterogeneous catalysts for environmental remediation

Yarong Fang, Yanbing Guo*

Central China Normal University

This review presents a comprehensive discussion on recent progresses of copper-based non-precious metal heterogeneous catalysts for various environmental remediation reactions, as well as a detailed analysis of catalysts structure-reactivity relationship.

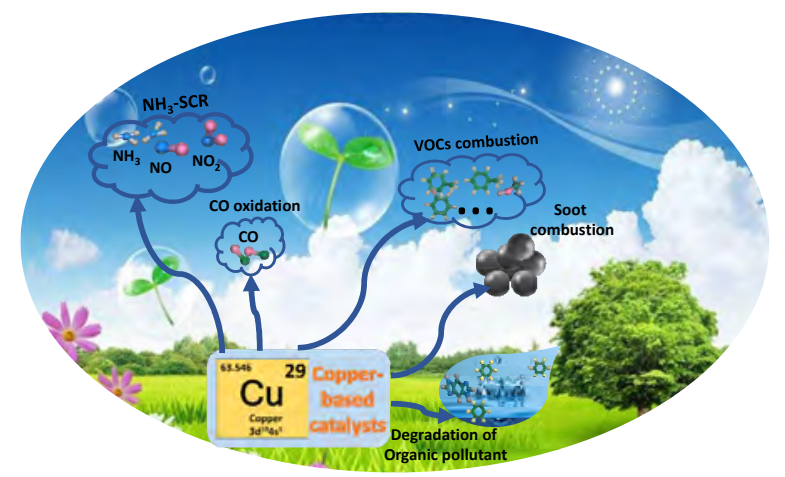


2009, 1,247-251

[70] M. Krämer, T. Schmidt, K. Stöwe, W. F. Maier, Appl. Catal. A, 2006, 302, 257-263.

[71] Z. G. Liu, S. H. Chai, A. Binder, Y. Y. Li, L. T. Ji, S. Dai, Appl. Catal. A, 2013, 451, 282-288.

[72] Z. G. Liu, Z. L. Wu, X. H, Peng, A. Binder, S. H. Chai, S. Dai, J. Phys. Chem. C, 2014, 118, 27870-27877.

[73] F. Gao, E. D. Walter, E. M. Karp, J. Y. Luo, R. G. Tonkyn, J. H. Kwak, J. Szanyi, C. H. F. Peden, J. Catal., 2013, 300, 20-29.

[74] G. Busca, L. Lietti, G. Ramis, F. Berti, Appl. Catal. B, 1998, 18, 1-36.

[75] M. Q. Shen, C. X. Li, Q. J. J. Wang, L. L. Xu, W. L. Wang, J. Wang, RSC Adv., 2015, 5, 35155-35165.

[76] B. J. Dou, G. Lü, C. Wang, Q. L. Hao, K. S. Hui, Chem. Eng. J., 2015, 270, 549-556.

[77] U. De-La-Torre, B. Pereda-Ayo, M. Moliner, J. R. González-Velasco, A. Corma, Appl. Catal. B, 2016, 187, 419-427.

[78] J. H. Kwak, R. G. Tonkyn, D. H. Kim, J. Szanyi, C. H. F. Peden, J. Catal., 2010, 275, 187-190.

[79] B. H. Chen, R. N. Xu, R. D. Zhang, N. Liu, Environ. Sci. Technol., 2014, 48, 13909-13916.

[80] M. Iwamoto, H. Furukawa, Y. Mine, F. Uemura, S. Mikuriya, S. Kagawa, J. Chem. Soc. Chem. Commun., 1986, 1272-1273.

[81] S. Brandenberger, O. Kröcher, A. Tissler, R. Althoff, Catal. Rev. Sci. Eng., 2008, 50, 492-531.

[82] F. Gao, E. D. Walter, M. Kollar, Y. L. Wang, J. Szanyi, C. H. F. Peden, J. Catal., 2014, 319, 1-14.

[83] D. W. Fickel, E. D’Addio, J. A. Lauterbach, R. F. Lobo, Appl. Catal. B, 2011, 102, 441-448.

[84] J. H. Kwak, D. Tran, S. D. Burton, J. Szanyi, J. H. Lee, C. H. F. Peden, J. Catal., 2012, 287, 203-209.

[85] J. R. Li, R. J. Kuppler, H. C. Zhou, Chem. Soc. Rev., 2009, 38, 1477-1504.

[86] J. Y. Luo, F. Gao, K. Kamasamudram, N. Currier, C. H. F. Peden, A. Yezerets, J. Catal., 2017, 348, 291-299.

[87] F. Bin, C. L. Song, G. Lü, J. O. Song, S. H. Wu, X. D. Li, Appl. Catal. B, 2014, 150-151, 532-543.

[88] G. Centi, S. Perathoner, Appl. Catal. A, 1995, 132, 179-259.

[89] U. Deka, A. Juhin, E. A. Eilertsen, H. Emerich, M. A. Green, S. T. Korhonen, B. M. Weckhuysen, A. M. Beale, J. Phys. Chem. C, 2012, 116, 4809-4818.

[90] P. S. Metkar, V. Balakotaiah, M. P. Harold, Chem. Eng. Sci., 2011, 66, 5192-5203.

[91] C. Paolucci, I. Khurana, A. A. Parekh, S. Li, A. J. Shih, H. Li, J. R. Di Iorio, J. D. Albarracin-caballero, A. Yezerets, J. T. Miller, W. N. Delgass, F. H. Ribeiro, W. F. Schneider, R. Gounder, Science, 2017, 357, 898-903.

[92] B. Yilmaz, N. Trukhan, U. Müller, Chin. J. Catal., 2012, 33, 3-10.

[93] M. M. Xing, Q. Sun, C. Zeng, H. Z. Wang, D. Zhao, N. Zhang, S .G. Hong, RSC Adv., 2017, 7, 18830-18837.

[94] P. O. Larsson, A. Andersson, J. Catal., 1998, 179, 72-89.

[95] H. Rotter, M. V. Landau, M. Carrera, D. Goldfarb, M. Herskowitz, Appl. Catal. B, 2004, 47, 111-126.

[96] S. C. Kim, J. Hazard. Mater., 2002, 91, 285-299.

[97] D. Delimaris, T. Ioannides, Appl. Catal. B, 2008, 84, 303-312.

[98] Q. Hua, T. Cao, X. K. Gu, J. Q. Lu, Z. Q. Jiang, X. R. Pan, L. F. Luo, W. X. Li, W. X. Huang, Angew. Chem. Int. Ed., 2014, 53, 4856-4861.

[99] Z. Luo, S. A. Cetegen, R. Miao, T. Jiang, S. Y. Chen, T. Jafari, Y. S. Zhang, S. L. Suib, J. Catal., 2016, 338, 94-103.

[100] C. He, Y. K. Yu, L. Yue, N. L. Qiao, J. J. Li, Q. Shen, W. J. Yu, J. S. Chen, Z. P. Hao, Appl. Catal. B, 2014, 147, 156-166.

[101]C. Q. Hu, Q. S. Zhu, Z. Jiang, Y. Y. Zhang, Y. Wang, Microporous Mesoporous Mater., 2008, 113, 427-434.
[102] E. M. Cordi, P. J. O, Neill, J. L. Falconer, Appl. Catal. B, 1997, 14, 23-36.

[103] H. F. Lu, Y. F. Chen, X. X. Kong, H. F. Huang, Y. Zhou, J. Environ. Sci. (China), 2015, 32, 102-107.

[104] D. Delimaris, T. Ioannides, Appl. Catal. B, 2009, 89, 295-302.

[105] M. R. Morales, B. P. Barbero, L. E. Cadús, Appl. Catal. B, 2006, 67, 229-236.

[106] H. F. Lu, Y. Zhou, H. F. Huang, B. Zhang, Y. F. Chen, J. Rare Earths, 2011, 29, 855-860.

[107] M. A. Oturan, J. J. Aaron, Crit. Rev. Environ. Sci. Technol., 2014, 44, 2577-2641.

[108] L. L. Zhang, D. Xu, C. Hu, Y. L. Shi, Appl. Catal. B, 2017, 207, 9-16.

[109] S. K. Ling, S. Wang, Y. Peng, J. Hazard. Mater., 2010, 178, 385-389.

[110] A. Angi, D. Sanli, C. Erkey, Ö. Birer, Ultrason. Sonochem., 2014, 21, 854-859.

[111] S. Saha, S. B. A. Hamid, T. H. Ali, Appl. Surf. Sci., 2017, 394, 205-218.

[112] L. Lai, L. L. Zhang, Q. Y. Wang, Y. L. Nie, C. Hu, Environ. Sci. Technol., 2015, 49, 8639-8647.

[113] B. K. Ghosh, S. Hazra, B. Naik, N. N. Ghosh, Powder Technol., 2015, 269, 371-378.

[114] A. C. Pradhan, B. Nanda, K. M. Parida, M. Das, Dalton. Trans., 2013, 42, 558-566.

[115] Priyanka, V. Subbaramaiah, V. C. Srivastava, I. D. Mall, Sep. Purif. Technol., 2014, 125, 284-290.

[116] Y. B. Wang, H. Y. Zhao, G. H. Zhao, Appl. Catal. B, 2015, 164, 396-406.

[117] Y. Lei, C. S. Chen, Y. J. Tu, Y. H. Huang, H. Zhang, Environ. Sci. Technol., 2015, 49, 6838-6845.

[118] Y. B. Wang, H. Y. Zhao, M. M. Li, J. Q. Fan, G. H. Zhao, Appl. Catal. B, 2014, 147, 534-545.

[119] C. Sun, R. Zhou, Jianan. E, J. Q. Sun, H. J. Ren, RSC Adv., 2015, 5, 57058-57066.

[120] Y. Lei, C. S. Chen, Y. J. Tu, Y. H. Huang, H. Zhang, Environ. Sci. Technol., 2015, 49, 6838-6845.

[121] S. Kalal, N. P. Singh Chauhan, N. Ameta, R. Ameta, S. Kumar, P. B. Punjabi, Korean J. Chem. Eng., 2014, 31, 2183-2191.

[122] C. M. Cao, Y. X. Zhang, D. S. Liu, M. Meng, Small, 2015, 11, 3659-3664.

[123] Y. F. Yu, M. Meng, F. F. Dai, Nanoscale, 2013, 5, 904-909.

[124] P. Sudarsanam, B. Hillary, B. Mallesham, B. G. Rao, M. H. Amin, A. Nafady, A. M. Alsalme, B. M. Reddy, S. K. Bhargava, Langmuir, 2016, 32, 2208-2215.

[125] M. Piumetti, S. Bensaid, T. Andana, N. Russo, R. Pirone, D. Fino, Appl. Catal. B, 2016, 205, 455-468.

[126] E. Aneggi, D. Wiater, C. de Leitenburg, J. Llorca, A. Trovarelli, ACS Catal., 2014, 4, 172-181.

[127] Q. Liang, X. D. Wu, D. Weng, H. T. Xu, Catal. Today, 2008, 139, 113-118.

[128] J. Giménez-Mañogil, A. Bueno-López, A. García-García, Appl. Catal. B, 2014, 152-153, 99-107.

[129] J. Giménez-Mañogil, A. García-García, Appl. Catal. A, 2017, 542, 226-239.

[130] J. Yang, Y. B. Guo, Chin. Chem. Lett. 2017, DOI 10.1016/j.cclet.2017.09.013.

[131] F. E. López-Suárez, A. Bueno-López, M. J. Illán-Gómez, A. Adamski, B. Ura, J. Trawczynski, Environ. Sci. Technol., 2008, 42, 7670-7675.

[132] Z. Q. Li, M. Meng, Y. Q. Zha, F. F. Dai, T. D. Hu, Y. N. Xie, J. Zhang, Appl. Catal. B, 2012, 121-122, 65-74. 


\title{
铜基非贵金属异相催化剂在环境修复中的应用
}

\author{
方亚蓉, 郭彦炳 ${ }^{*}$ \\ 华中师范大学化学学院环境与应用化学研究所, 农药与化学生物学教育部重点实验室, 湖北武汉430079
}

\begin{abstract}
摘要: 近年来, 全球经济和工业高速发展带来的环境问题, 不仅严重影响着经济社会的可持续发展, 更极大地危害着人类 健康. 石油化工、医药生产和交通运输等过程产生的气、液、固相污染物可直接或间接造成臭氧层空洞、光化学烟雾及 水体污染等重大环境问题. 气相污染物中, CO和可挥发性有机物(VOCs)不仅具有生物毒性, 更是形成光化学烟雾等大气 污染的主要前驱体. $\mathrm{NO}_{x}$ 和 $\mathrm{SO}_{2}$ 会造成酸雨的形成, 极大地破坏生态系统. 工业废水中难分解的有机污染物可对环境造成 持续性破坏. 而不完全燃烧产生的碳烟颗粒物不仅影响气候和大气环境, 同时可导致心血管疾病高发, 危害人体健康. 源 头控制是环境污染治理的关键, 而催化净化是当前污染物源头控制最有效的技术之一. 因此, 设计和开发稳定、高效的环 境修复催化剂是科学家们面临的一个关键问题. 传统贵金属(Pt, Rh, Pd)催化剂虽然催化活性高, 但是存在价格昂贵且易中 毒等不足. 而过渡金属及其氧化物因具有高活性、价格低廉和高储量等特点有望成为贵金属的替代催化剂.

铜是具有 $3 d$ 轨道的过渡金属, 有活泼的物理化学性质, 是工业中大量应用的有色金属. 铜基氧化物因高氧化还原电势 和低环境危害被广泛应用于热催化、电催化和光催化. 基于文献报道, 铜基催化剂主要分为三类: 铜氧化物 $\left(\mathrm{CuO}_{x}\right)$, 负载型 铜氧化物 $\left(\mathrm{CuO}_{x} /\right.$ support $)$ 和固溶体铜氧化物 $\left(\mathrm{CuO}_{x}-\mathrm{X}\right)$. 本篇综述首先探讨了铜氧化物的价态、晶体结构、形貌、暴露晶面 以及载体与催化剂活性之间的内在联系, 阐明铜基催化剂结构与性能的构效关系及高效催化剂的设计原则; 继而全面总 结了近年来不同类型的铜基材料在催化净化环境污染物中的应用, 主要介绍了以下5类反应: CO的催化氧化, $\mathrm{NO}_{x}$ 的选择 性催化还原(SCR), VOCs的完全燃烧, 废水中有机污染物降解, 以及碳烟颗粒物催化燃烧. 我们深入阐述铜氧化物的催化 活性位点和催化机制; 分析负载型铜基催化剂的比表面积、分散度、协同作用和界面作用对催化剂的活性和稳定性的影 响; 阐明固溶体催化剂的独特原子组成设计与性能关系, 为高效催化剂设计提供思路. 此外, 本综述对铜基催化剂在环境 催化中的研究现状以及尚未解决的问题进行了剖析与展望. 通过铜氧化物表面调控, 复合催化剂的界面调控, 具有更高稳 定性和抗中毒性的高效催化剂有望开发成功, 而团簇及单原子铜催化剂也有望在此领域有所突破.
\end{abstract}

关键词: 铜基催化剂; 异相催化; $\mathrm{CO}$ 催化氧化; 选择性催化还原; 可挥发性有机物氧化; 有机污染物降解; 碳烟颗粒物催 化燃烧

收稿日期: 2017-11-30. 接受日期: 2017-12-31. 出版日期: 2018-04-05.

*通讯联系人. 电话: 17786507005; 电子信箱: guoyanbing@mail.ccnu.edu.cn

基金来源：国家“千人计划青年人才” 启动基金; 高等学校学科创新引智计划(111计划, B17019); 国家自然科学基金(21777051). 本文的电子版全文由Elsevier出版社在ScienceDirect上出版(http://www.sciencedirect.com/science/journal/18722067). 